NASA Technical Memôrandum 87102

\title{
Nonlinear Flap-Lag-Extensional Vibrations of Rotating, Pretwisted, Preconed Beams Including Coriolis Effects
}

K.B. Subrahmanyam and K.R.V. Kaza

Lewis Research Center

Cleveland, Ohio

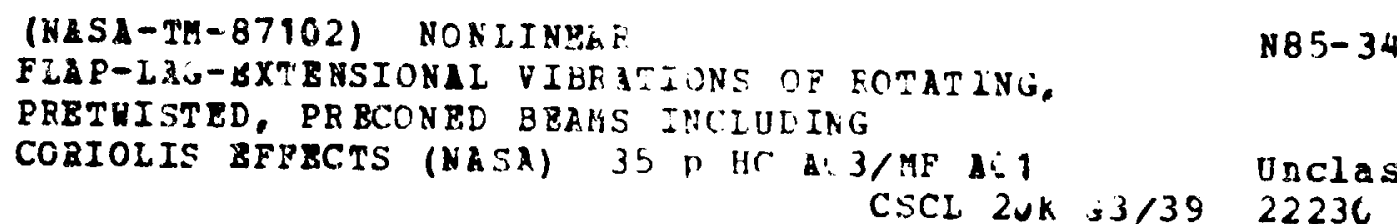

Prepared for the 19th Midwestern Mechanics Conference sponsored by The Ohio State University Columbus, Ohio, September 9-11, 1985

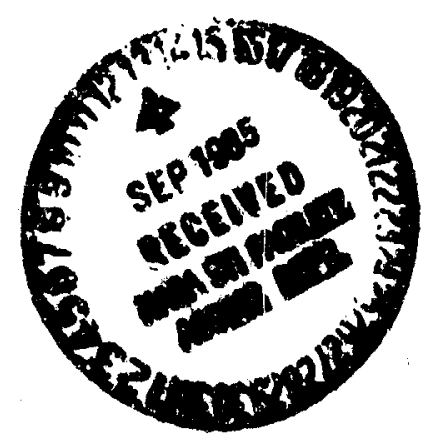


NONLINFAR FLAP-LAG-EXIENSIŪNALL VIOERATIOHS OF ROTATING,

PRETWISTED, PRFCONED BEAMS INCLUDING CORIOLIS EFFECTS

\author{
K.B. Subrahmanyam* and K.R.V. Kaza \\ National Aeronautics and Space Administration \\ Lewis Research Center \\ Cleveland, Ohio 44135
}

\title{
SUMMARY
} The effects of pretwist, precone, setting angle, corlolis forces and sec-
ond degree geometric nonlinearlties on the natural frequencies, steady state deflectlons and mode shapes of rotating, torsionally rigid, cantilevered beams are studied in this investigation. The governing coupled equations of flaplag-extensional motion are dertved including the effects of large precone (a component of sweep) and retaining geometric nonlinearities up to second degree. The Galerkin method, with nonrotating normal modes, is used for the solution of both steady state nonlinear equatiolis and linear perturbation equations. Parametric results indicating the indivisual and collective effects of pretwist, precone, Corlolis forces and second degree geometric nunlinearities on the steady state deflections, natural frequencles and mode shapes of rotating blades are presented anc discussed. The results indicate that the second degree geometric nonlinear terms, which vanish for zerc precone, can produce frequency changes of engineering significance (of the order of 20 percent on the fundamental mode, and about \pm 4 percent on the second mode). Further confirmation of the validity of including second degree nonlinearities in the analysis is achleved by comparisons of beam theory results to those generated by MSC NASTRAN. The results further indicate that the $11 \%$, r and nonlinear Coriolis effects must be included in analyzing thick blat? while these effects can be neglected in analyzing thin blades, typlcal of advanced turboprop blade configurations. The corfolis effects are significant on the first flatwise and the first edgewise modes, but are insignificant on higher modes. For those mode; where the effect is significant, the linear and nonilinear coriolis effects oppose one another, the nonlinear effects generally being stronger.

\section{INTRODUCTION}

An important phase in the development of advanced turboprop blades, currently in progress at the Lewls Research Center, is the development of analytical blade models that can predict the vibration and flutter characteristics with acceptable accuracy. The turboprop blades are of thin cross sections with large, varlable sweep, and are mounted on a rotating hub at a setting angle. Moreover, the blades are subjected to considerable centrliugal loading which causes steady state deflections that are large compared to the blade thickness. it is therefore necessary to include geometric nonlinearlties of a sufficlent degree, together with other relevant blade complexities in the analysis of turboprop blades.

*On leave from NBKR Institute of Sclence and Technology, Mechanical Englneering Department, Vidyanagar 524413, Indla and presently Research Associate, Untversity of Toledo. Toledo, Onto 43606. 
Several methods of solution making use of a beam, plate or shell theory are avallable for the snlutinn of stralght, rotating, asymmetrir cross section blades (refs. 1 to 3 ). The coupled equations of motion of such blades based on efther linear theory (refs. 4 to 6). or geometric nonlinear theory allowing for small precone (refs. 7 to 9 , to mention a few) are avallable. However, the cquations of motion including large varlable sweep for blades of advanced turboprop type configurations are not yet avallabie. While finite-element modeling of the turboprop blades appears to be the most approprlate method for blades of such complex geometry, such studies with the existing codes at the Lewts Research Center revealed that the predicted results are satisfactory only for the first few modes. Furthermore, the complicating effects included in the finite element codes, and also in the plate and shell theorles, make the understanding of the individual and coilective effects of the governing parameters impossible. In order to conduct parametric studies to assess the varlous complicating effects, and to acquire a physical understanding of the complex blade dynamic problem, it is proposef to use a simpler beam theory to model the rotating blade with the complicating effects successively taken into account to reveal the relative importance of the individual and collective effects. A preliminary study made by using a set of linear equations of motion of a torsionally rigld, pretwisted, rotating blade including Corlolis effects was reported in reference 10 wherein the effects of sweep on the dynamic behavior were introduced by preconing the blade with respect to the plane of rotation. The effects of linear pretwist, precone and linear Corlolis effects in the vibration and stabllity of rotating blades were fiscussed in reference 10, and it was pointed out that the Coriolis effects must be included in the analysis of thick blades but could be disregarded in analyzing thin blades possessing small pretwists. The position and width of an instabllity region was shown to be dependent on the extent of pretwist, precone and whether or noi the corlolis effects were included in the analysis. Although the blade was considered to be torsionally rigid, and hence the results somewhat restricted in generality, considerable information on the various governing parameters was obtained. The first objective of the present effort is to determine the effect of second degree geoinetric nonlinearities on the natural frequencles, steady state deflections and mode shapes of the blade cases considered in the prevtous investigation (ref. 10). The second objective is to find the parameter limits within which the second degree geometric nonlinearities are adequate to properly represent the blade dynamic characteristics, by comparison of results produced by beam theory to those produced by MSC NASTRAN. It may be noted here that only the second degree geometric nonlinear effects are included in the present beam theory together with Coriolis effects. Further, there is no restriction on the degree of nonlinearity in the MSC NASTRAN although the Corfolis effects are not accounted by this finite element code. Thus, a fair comparison of frequencles and steady state deflectlons produced by the present beam theory to those from MSC NASTRAN (for such blade conflgurations that are insensitive to both linear and nonlinear Corlolis forces) would establish the validity of the restriction of the nonlinearities to only the the second degree. Further complexitles of torsional, extensional, rotational and warping couplings can then be addressed once the accuracies of the present restricted beam model are properly validated.

In order to accomplish the stated objectives, the required equations of motion are derived by using the theory presented in reference 9, and by retaining geometric nonlinearitles up to second degree. The Galerkin method, with nonrotating normal modes, is employed for the solution of both steady state nonilinear equations and itneartzed perturbation equations. Parametric 
studies are conducted to assess the effects of the varlous terms for configurations representalive of piopei iei tiaues and audvanced tuiboprop blades. The formulation and solution procedures of the equations of motion are briefly presented in what follows, together with the detalled parametric results and a discussion.

\section{EQUATIONS OF MOTION ANU METHOO OF SOLUTION}

The coupled flap-lag-extensional equations of motion of a rotating, torstonally rigid, linearly pretwlsted and preconed blade of untform rectangular cross section, shown in figure 1. including Corlolis effects and second degree geometric nonilinearities but disregarding all other higher order effects, can be derfved by using the theory presented in references 9 and 11 . Such equations are presented below (a 11st of notation is given in appendix $B$ ):

Flatwise bending:

$$
\begin{aligned}
\min & -m^{2} w \sin ^{2} B_{P C}+2 m \Omega \dot{v} \sin B_{P C}+m \Omega^{2} \sin B_{P C} \cos B_{P C}\left(x+u-u_{F}\right)-\left(T^{\prime}\right)^{\prime} \\
& +\left\{w^{\prime \prime}\left(E I_{n \eta} \cos ^{2} \theta+E I_{\xi \xi} \sin ^{2} \theta\right)+v^{\prime \prime}\left(E I_{E \xi}-E I_{n \eta}\right) \sin \theta \cos \theta\right\}^{\prime \prime}= \\
& -\left\{\Omega^{2} \sin B_{P C} \cos B_{P C} \rho\left(I_{E \xi} \sin ^{2} e+I_{n \eta} \cos ^{2} \theta\right)\right\}
\end{aligned}
$$

Edgewtse bending:

$$
\begin{aligned}
m \ddot{v} & -m \Omega^{2} v+2 m \Omega \cos \beta_{P C}\left(\dot{u}-\dot{u}_{F}\right)-2 m \Omega \dot{w} \sin \beta_{P C}-\left(T v^{\prime}\right)^{\prime} \\
& +\left\{w^{\prime \prime}\left(E I_{\xi \xi}-E I_{n \eta}\right) \sin \theta \cos \theta+v^{\prime \prime}\left(E I_{n \eta} \sin ^{2} \theta+E I_{\xi \xi} \cos ^{2} \theta\right\}^{\prime \prime}=\right. \\
& -\left\{\Omega^{2} \sin \beta_{P C} \cos \beta_{P C} \rho\left(I_{\xi \xi}-I_{n n}\right) \sin \theta \cos \theta\right\}^{\prime}
\end{aligned}
$$

Extension:

$$
\begin{aligned}
m\left[\ddot{u}-\ddot{u}_{F}-\Omega^{2} \cos ^{2} B_{P C}\left(u-u_{F}+x\right)+w \Omega^{2} \sin B_{P C} \cos B_{P C}\right. & \left.-2 \dot{v} \Omega \cos B_{P C}\right]-\left(A E u^{\prime}\right),=0
\end{aligned}
$$

where

$$
\begin{aligned}
T-\int_{x}^{1} m\left[\ddot{u}-\ddot{u}_{f}-\Omega^{2}\left(R+x-u_{F}\right) \cos ^{2} B_{P C}\right. & -2 \Omega \dot{v} \cos B_{P C} \\
& \left.+\Omega^{2} w \cos \beta_{P C} \sin \beta_{P C}\right] d x,
\end{aligned}
$$




$$
u_{f}=\frac{1}{x} \int_{\delta}^{x}\left(v^{\prime 2}+w^{\prime 2}\right) d x,
$$

and

$m=\iint \rho d y d z, A=\iint d y d z, I_{\xi \xi}=\iint y^{2} d y d z, I_{n n}=\iint z^{2} d y d z$,

$$
()^{\prime}=\frac{\partial}{\partial x}(),\left(^{\circ}\right)=\frac{\partial}{\partial t}()
$$

Defining the following parameters,

$$
\bar{w}=w / L, \bar{v}=v / L, n=x / L, \tau=\Omega t, \bar{R}=R / L \text {, etc. },
$$

assuming solutions are separable in time and space, and making note of the following relations

$$
\frac{d}{d x}=\frac{d}{d \eta} \cdot \frac{d \eta}{d x}=\frac{1}{L} \frac{d}{d \eta} \cdot \frac{d}{d t}=\Omega \frac{d}{d \tau} \text { etc. } .
$$

one can rewrite equations (1) to (3) in the following nondimensional forms:

$$
\begin{aligned}
& \ddot{\bar{w}}+2 \sin \beta_{P c} \dot{\bar{v}}-\bar{w} \sin ^{2} \beta_{P c}-\frac{1}{2} \sin \beta_{P c} \cos \beta_{P c} \int_{0}^{n}\left(\bar{v}^{2}{ }^{2}+\bar{w}^{2}\right) d n \\
& -\cos ^{2} B_{P C}\left(\bar{w}^{\prime \prime} Q-\bar{w}^{\prime} S\right)-2 \cos \beta_{p c}\left[\bar{w}^{\prime \prime} \int_{n}^{1} \dot{\bar{v}} d n-\bar{w}^{\prime} \dot{\bar{v}}\right] \\
& +\sin \beta_{P c} \cos \beta_{P c}\left[\bar{w} " \int_{n}^{1} \bar{w} d n-\bar{w} \cdot \bar{w}\right]+\xi \bar{w}^{-i v}\left(\cos ^{2} \theta+\frac{b^{2}}{d^{2}} \sin ^{2} \theta\right) \\
& +\bar{w}^{\prime \prime \prime}(2 \gamma \xi \sin 2 \theta)\left(\frac{b^{2}}{d^{2}}-1\right)+\bar{w}^{\prime \prime}\left(2 \gamma^{2} \xi \cos 2 \theta\right)\left(\frac{b^{2}}{d^{2}}-1\right)+\xi \bar{v}+v\left(\frac{1}{2} \sin 2 \theta\right)\left(\frac{b^{2}}{d^{2}}-1\right) \\
& +\bar{v}^{\prime \prime} \cdot(2 \gamma \xi \cos 2 \theta)\left(\frac{b^{2}}{d^{2}}-1\right)-\bar{v}^{\prime \prime}\left(2 \gamma^{2} \xi \sin 2 \theta\right)\left(\frac{b^{2}}{d^{2}}-1\right)+\sin \beta_{P c} \cos \beta_{P c} \bar{u} \\
& +\bar{w}^{\prime \prime} \int_{\eta}^{1} \ddot{\bar{u}} d \eta-\bar{w} " \int_{\eta}^{1} \bar{u} \cos ^{2} \beta_{P c} d \eta-\bar{w} \cdot \ddot{\bar{u}}+\bar{w}^{\prime} \bar{u} \cos ^{2} \beta_{P c} \\
& =-n \sin \beta_{P c} \cos \beta_{P C}-\frac{I \eta \eta}{A L^{2}}\left(\frac{b^{2}}{d^{2}}-1\right) \sin \beta_{P C} \cos \beta_{P C} \sin 2 \theta
\end{aligned}
$$




$$
\begin{aligned}
& \ddot{\bar{v}}-2 \sin \beta_{p_{c}} \dot{\bar{w}}-\bar{v}-\cos ^{2} \beta_{P C}\left(\bar{v}^{\prime \prime} Q-\bar{v}^{\prime} S\right)-2 \cos \beta_{F_{i}}\left[\bar{v}^{\prime \prime} \int_{n}^{1} \dot{\bar{v}} d n-\bar{v}^{\prime} \dot{\bar{v}}\right] \\
& -\cos \beta_{P C} \frac{d}{d \tau} \int_{0}^{\eta}\left(\bar{v}^{\prime 2}+\bar{w}^{\prime 2}\right) d \eta+\sin \beta_{P C} \cos \beta_{P C}\left[\bar{v}^{\prime \prime} \int_{\eta}^{1} \bar{w} d \eta-\bar{v}^{\prime} \bar{w}\right] \\
& +\bar{w}^{i v} \xi\left(\frac{1}{2} \sin 2 \theta\right)\left(\frac{b^{2}}{d^{2}}-1\right)+\bar{w}^{\prime \prime}(2 \gamma \xi \cos 2 \theta)\left(\frac{b^{2}}{d^{2}}-1\right) \\
& -\bar{w}^{\prime \prime}\left(2 \gamma^{2} \xi \sin 2 \theta\right)\left(\frac{b^{2}}{d^{2}}-1\right)+\bar{v}^{i v} \xi\left(\sin ^{2} \theta+\frac{b^{2}}{d^{2}} \cos ^{2} \theta\right)-\bar{v}^{\prime \prime}(2 \gamma \xi \sin 2 \theta)\left(\frac{b^{2}}{d^{2}}-1\right) \\
& -\bar{v}^{\prime \prime}\left(2 \gamma^{2} \xi \cos 2 \theta\right)\left(\frac{b^{2}}{d^{2}}-1\right)+2 \cos \beta_{P C} \dot{\bar{u}}-\bar{v}^{\prime \prime} \int_{n}^{1} \bar{u} \cos ^{2} \beta_{P C} d \eta \\
& +\bar{v}^{\prime \prime} \int_{\eta}^{1} \ddot{\bar{u}} d \eta-\bar{v} \cdot \ddot{\bar{u}}+\bar{v} \cdot \bar{u} \cos ^{2} \beta_{P C}=-\sin \beta_{P C} \cos B_{P C}\left(\frac{I_{\eta \eta^{\gamma}}}{A L^{2}}\right) \cos 2 \theta \\
& \ddot{\ddot{u}}-\left[\frac{d^{2}}{d \tau^{2}} \frac{1}{2} \int_{0}^{n}\left(\bar{v}^{\prime 2}+\bar{w}{ }^{2}\right) d \eta\right]-\cos ^{2} \beta_{P c} \bar{u}+\frac{1}{2} \cos ^{2} \beta_{P c} \int_{0}^{n}\left(\bar{v}{ }^{2}+\bar{w}{ }^{2}\right) d \eta \\
& +\bar{w} \sin \beta_{P C} \cos \beta_{P C}-2 \dot{\bar{v}} \cos \beta_{P C}-\left(A E / m \Omega^{2} L^{2}\right) \bar{u} "=\eta \cos ^{2} B_{P C}
\end{aligned}
$$

where

$$
\begin{array}{r}
Q=R(1-\eta)+0.5\left(1-\eta^{2}\right), S=(k+\eta),(\bar{w})^{\prime}=\frac{d}{d \eta}(\bar{w}),(\dot{\bar{w}})=\frac{d}{d \tau}(\bar{w}), \\
\xi=\left(E I_{n \eta} / \rho A L^{4} \Omega^{2}\right), \text { and } \theta=\varphi+\gamma n
\end{array}
$$

Before discussing the method of solution, it is worthwhile to point out the various important linear terms assoclated with precone, and also the noninear terms extsting in the present equations. The linear terms assoclated with precone are addressed first. Referring to equation (9), one can see that a linear softening term, $\left(-\bar{w} s / n^{2} B p c\right)$, appears in the flap equation. This term vanishes for zero precone, but lecomes an important term for sultably large values of precone and rotational speeds, and contributes to the mechanism of rotation induced instablilty. Next, the terms $\left(2 \sin B_{p c} \overline{\bar{v}}\right)$ and $(-2 \sin$ $\left.B_{p c} \bar{W}\right)$ in equations (9) and (10) respectively are the linear corlolis forco terms that arise due to the inclusion of precone. The effect of these terms on the linear frequencles has been discussed in detall in reference 10 . Considering equation (11), one observes that there is one linear term ( $\bar{w}$ sin $B \mathrm{PC}$ $\cos B_{p c}$ ). which vanishes for zero precone, and that the linear Cortolis force term $\left(2 \dot{\bar{v}} \cos B p_{C}\right)$ appears in this equation whether or not precone is present 
in the derivation of the equations. Since it will be shown that the inclusion of extensional degree of freedom is not that important for anaiyzing botii tiin and thick blades, further discussion of the other nonlinear terms assoclated with the extensional deformation will not be attempted in this section. Next the important nonlinear terms existing in equations (9) and (10) are considered. The nonlinear Corlolis force terms are shown by underlining them once, and these terms will be present in the equations even when precone is absent. The nonlinear terms which are shown by underscoring them twice in equations (9) and (10) are the contributions from the tension terms (TW')' and (TV')', as are two of the three nonlinear Coriolis terms just discussed. Howeve, the doubly underlined terms vanish for zero precone. Finally, the term shown by broken uriderining is the effect of foreshortening of the blade. This term also vanishes for zero precone. It may also be mentioned here that for the limiting case value of $90^{\circ}$ precone, all nonlinear terms in equations (9) to (11) vanish excepting those assoclated with extensional inertia (iu, $u_{F}$ ). Since the nonlinear terms assoclated with extensional deformation are already noted to be unimportant, the effect of geometric nonlinearities should become almost neg$11 \mathrm{~g}$ ible at $B P_{C}=90^{\circ}$.

The flap-lag-extenstional equations are solved by the Galerkin method by assumir.g that the dimensioniess bending and extensional defiections in terms of a serles of generalized coordinates and mode shape functions are as follows:

$$
\begin{aligned}
& \bar{w}=\sum_{j}\left(w_{0 j}+\Delta w_{j}(\tau)\right) \Psi_{j}(n) \\
& \bar{v}=\sum_{j}\left(v_{0 j}+\Delta v_{j}(\tau)\right) \Psi_{j}(n) \\
& \ddot{u}=\sum_{j}\left(u_{0 j}+\Delta u_{j}(\tau)\right) \theta_{j}(n)
\end{aligned}
$$

where

$$
\begin{gathered}
\Psi_{j}(n)=\cosh \left(\beta_{j} n\right)-\cos \left(\beta_{j} n\right)-\alpha_{j}\left[\sinh \left(\beta_{j} n\right)-\sin \left(\beta_{j} n\right)\right] \\
\theta_{j}(n)=2 \sin \left(\gamma_{j} n\right) \\
\gamma_{j}=\pi\left(j-\frac{1}{2}\right)
\end{gathered}
$$

Equations (16) to (18) are the nonrotating normal modes for a cantilevered beam fixed at $n=0$, and free at $n=1$. Furthermore, the quantities $w_{0 j}, v_{0}$ and $u_{0 j}$ in the generalized coordinates constitute the equilibrium quantities while $\Delta w_{j}, \Delta v_{j}$ and $\Delta u_{j}$ are the perturbation quantities.

By substitciting only the steady state equiliurlum quantities into the nonlinear equatiuns (9) to (11), assuming n-normal modes for each of the var1ables $\bar{u}, \bar{v}$, and $\bar{w}$ and carrying out the Galerkin process traditionaily, one obtains a set of $3 n$ nonlinear equations in terms of $w_{0 j}$. $v_{0 j}$ and $u_{0 j}$. The constants of and $B_{j}$ are taken from reference 12 , and the resulting equilibrium equations are solved by usirig a computer program based upon a fintte-difference Levenberg-Marquardt algorithm (ref. 13). Next, 
equat!nns (13) to (15) are substituted into equations (9) to (11), the Galerkin process is carrled out again, the equilibrium equatiuns aie subtracted from the result, and all nonlinear quantities in the perturbation parameters are discarded to obtain ti.e linear perturbation equations (expressed in teinis of the equilibrium generalized coordinates) that define the unsteady blade motion ahout the equilibrium operating condition. The steady state equilibrium equa$t$ iuns, and the linear perturbation equations are written in the following matrix notations:

$$
\begin{gathered}
{[\underset{\sim}{L}]\left\{X_{0}\right\}+[\underset{\sim}{N L}]\left\{X_{0}\right\}=\{B\}} \\
{[\underset{\sim}{M}]\{\dot{X}\}+[\underset{\sim}{C}]\{\dot{X}\}+[\underset{\sim}{K}]\{X\}=0}
\end{gathered}
$$

where

$$
\begin{aligned}
& x_{0}=\left\{w_{01}, w_{02}, \ldots, w_{0 n}, v_{01}, v_{02}, \ldots, v_{0 n}, u_{01}, u_{02}, \cdots,\right. \\
& x=\left\{\Delta w_{1}, \Delta w_{2}, \ldots, \Delta w_{n}, \Delta v_{1}, \Delta v_{2}, \ldots, v_{n}\right\}, \Delta u_{1}, \Delta u_{2}, \ldots, \cdot \\
& \left.\Delta u_{n},\right\},
\end{aligned}
$$

with $\downarrow$ and $L N$ being respectlyely the linear and nonlinear parts of the

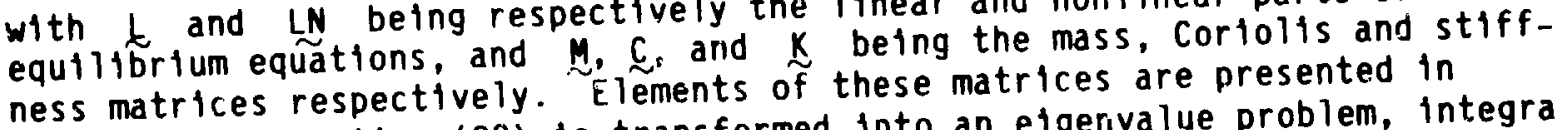
appendix A. Equation (20) is transformed into an eigenvalue problem, integrations are performed using a Gaussian quadrature formula, and the steady state deflections, eigenvalues and elgenvectors are determined for varlous cases of rotating blades.

\section{RESULTS AND DISCUSSION}

The nonlinear steady state equations (19), and the elgenvalue problem that results from the transformation of equation (20) were solved by using computer programs developed in FORTRAN language. The general computer program developed for the solution of equation (20) gives the natural frequencies per urit rotationa? speed, $(p / \Omega)$. In the presence of Corfolis effects, the frequencies will occur in pairs of purely imaginary quantities for a conservative system. In the absence of Corlolis effects, the fiequency equation (20) reduces to a standard elgenvalue problem, the elyenvalues of which are real quantities of $\left(p^{2} / \Omega^{2}\right)$. Thus, spectalized simple cases were solved by modifying the general computer program. Typical thickness ratios which approximately represent advanced turboprop blades $(d / b=0.05)$ or propeller blades $(d / b=0.25)$ were considered for aspect ratios of the crder of 5 to 10 . It may be noted that the radius of the disc, $R$, is assumed to be zero for simplicity. 


\section{Convergence}

The convergence of solutions produced by the Galerkin method for the coupled flap-lag-extension equations, using vartous numbers of nonrotating normal modes for the independent variables, is shown in table $I$. The blade considered for this convergence study has a precone of $30^{\circ}$ and a thickness ratio of 0.5 . The blade chord at the root is set perpendicular to the axis of rotation $\left(\varphi=0^{\circ}\right)$ and the blade rotational speed is one half of the fundamental mode frequency of the same nonrotating blade $(\Omega / \omega)=0.2$. Natural frequencies for this biade with zero pretwist are determined by varying the number of nonrotating normal modes, $n$, used in the sertes solution assumed. It can be seen from this table that a five-mode solution produces the frequencles of the linear equations, and also those from a perturbation solution of the nonlinear equations, converged tc five significant figures. A further comparison of the present flap-lag-extension frequencies, $\left(p / \lambda_{1}\right)$, obtained from the solution of the linear equations to those giver. in references 10 and 14 shows an excellent agreement. Further results for various combinations of pretwist, precone, setting angle and rotational speed are obtained by using a five-mode Galerkin solution, and the individuai and collsctive effects of the various parameters are discussed in the following sections. The validity of restricting the geometric nonlinearities to second degree only is assessed by comparison of the present beam theory results to those produced by MSC NASTRAN for specialized cases of thin blades in the following section.

\section{Comparison of Present Results}

Comparison of the frequencies from the solution of the present linear equations and those from a perturbation solution of the nonlinear equations is made to the frequencies produced by MSC NASTRAN using 250 COUAD 4 elemen'.s in tables II to IV for typical values of precone, rotational speed and tilickness ratio. The steady state equilibrium deflections produced by the present beam theory and those produced by MSC NASTRAN are compared in figure 2. Considering the results presented in table II corresponding to a thin blade possessing zero pretwist, zero precone and zero setting angle, one can see that the lowest sixmode frequencies obtained from perturbation solution of the beam theory equations agree to within one half of 1 percent with those given by MSC NASTRAN, for wide range of rotational speeds. It may be noted that the present flaplag-extensional equations cannot predict the torsional frequencies since this degree of freedom is not considered in this study. Next, a comparison of the lowest three frequencies of the same blade considered earlier but with a $15^{\circ}$ precone are presented in table III. A further comparison of linear and nonlinear frequencles is also made in this table. Here also, the agreement between the two sets of results is good. The effect of geometric nonifinearitles on the lowest three flatwise modes is seen to be of a stiffening character, and the frequencies are found to increase with increasing rotational speeds due to the nonlinearities. Table IV shows further comparison of results for large values of precone, for both thin and thick blade cases, at various rotational speeds. Considering the trend of results observed so far for thin blades, it is evident that the first bendirig modes in both flatwise and edgewise directions are affected much more than higher modes. The percent differelice between beam theory results and MSC NASTRAN results increases with increasing precone for a given rotational speed, and for a given precone with increasing rotational speeds. However, fer practical rotor speeds of the order of $\left(\Omega / \omega_{1}\right) \leq 1$, the difference between the two sets of results is not 
greater than 5 percent. When a comparison of the results obtained for thick blades $(d / b=0.25)$, is made, it appears that the percent error observed for the second mode is quite large. In order to assess the effect of ignoring the Coriolis effects, results for the thick blade cases are also obtained from the present beam theory by Ignoring the Corlolis effects, and these results are compared to the corresponding ones from MSC NASTRAN. These are also included in table IV. From thi: compa:ison of results, it is evident that the results frun MSC NASTP.AN are in closer agreement with the corresponding resulics from the beam theory when the Coriolis effects are ignored in beam theory. It should be noted here that the rather large difference observed for the second mode frequency of thick blades, (which is the fundamental edgewise frequency), may be partially attributed to the fact that the present slender beam approximation in the beam theory may be inadequate to predict the frequencies of stubby blades in general and the stiff edgewise mode frequencies in particular. Proper comparisons of these frequencles is only possible by including the shear and rotary inertia effects in both beam theory and MSC NASTRAN.

Next, the steady state deflections for thin blades given by the present beam theory are considered. For the untwisted blade cases considered in this work for varlous precones and rotational speeds, it is observed that the flatwise deflection is the must significant while the edgewise and extensional deflections were almost insignificant. The extensional deformation was found to be more significant than the edgewise deflection. However, for pretwisted blades, both flatwise and edgewise steady state deflections became quite significant, and the magnitudes of these deflections were found to be large in comparison to the corresponding untwisted blade deflections. Thus, for the untwisted, thin blade cases, the distribution of dimensionless flatwise deflection, $\bar{w}$, along the length of the blade obtained from the present beam theory is compared to the corresponding one from MSC NASTRAN in figures 2(a) to (d), for typical precones and rotational speeds. An examination of these results indicates that the trends shown by both sets of resu?ts considered are consistent. Furthermore, the agreement between the two sets of results is extremely close for low rotational speeds. The difference between beam theory resuits and MSC NASTRAN gradualiy increased from zero at the root section to the maximum at the tip in general. For precones of the order of $45^{\circ}$ and rotational speed parameter value of up to $(\Omega / \omega)=1.0$, the great st difference between the two sets of results, (steady state deflections and frequencles up to third mode), has been found to be of the order of 5 percent for thin blades. It is interesting to note that the deflections given by the beam theory are consistentiy greater than those produced by MSC NASTRAN.

From the foregoing discussion of results, it appears that the present beam theory, including geometric nonlinearities up to second degree only, predicts the natural frequencles and steady state de: lections to an acceptable degree of accuracy in the case of thin blades having precones of up to $45^{\circ}$ and for blade rotational speeds that are practically encountered in their applications. It is belleved that the inclusion of the torsional degree of freedom, which is necessary for calculation of stabllity boundartes for the blades, should not alter this trend of agreement of results, since the torsional mode coupling may affect the stabllity boundary but not the convergence of the first few modes that are well separated from the basic torstonal mode frequency. It may thus be concluded that the second degree nonlinearltles are adequate for modeling thin blades with large precone and for rotational speeds encountered in their practical operational range. 


\section{IḦOYYIOUAL AANO COLLECTIVE EFrECTS}

In order to understand the Individual and combined effects of, scie. linear and nonlinear Coriolis forces, various nonlinear terms (seco geometric nonlinearities) and pretwist on the frequencles of rotatin. parametric studies were conducted for two typical thickness ratios of $\_$.... 0.25 for varlous setting angles (collective pitch). These results ari presented in tables $V$ to $I X$. Flgure 3 shows the effect of setting angle, pretwist and precone variations on the fundamental mode frequency parameter, $\left(p_{1} / \lambda_{1}\right)$.

\section{Effect of Varying Precone}

In order to determina the effect of varying precone on the frequency parameter ratios of untwisted blades with zero setting angle $(\varphi=0)$, the flaplag-extension equations were solved for a typical rotational parameter value of $(\Omega / \omega\rceil)=1.0$. The value of precone was changed from $10^{\circ}$ to $50^{\circ}$, and the linear and nonlinear frequencies were determined which include the coriolis effect terms also. These frequencies are listed in table $v$ together with the percent frequency variation based upon the nonlinear frequency for each mode. The following obsarvations are made from the results presented in table $v$.

1. For a given rotational speed and thickness ratio, the flatwise mode frequencles decrease with increasing precone in the case of both linear and nonlinear theorles. Tie first edgewlse mode frequency, (refer the second mode frequency of thick blade with $d / b=0.25)$, given by linear equations or nonlinear equations shows an increasing trend with increasing precone.

2. The flatwise inode frequencies produced from the perturbation solution. of the nonlinear equations are higher than the corresponding frequencies obtained from the linear set of equations. The fundamental edgewise frequency given by the solution of nonlinear equations is lower than the corresponding ilnear solution value.

3. The effect of geometric nonlinearities, as rould be seen from the percent frequency variation, increases with increasing precones of up to $50^{\circ}$ considered here. The frequency change for flatwise modes is seen to be positive (stiffening) while for edgewlse modes it is negattve (softening). However, it should be noted that for $90^{\circ}$ precone, the effect of geometric nonlinearlties becomes almost zero as should be expected.

4. The fundamental mode frequency shows the strongest freciency variation (positive for flatwise mode and negative for edgewise mode) due to the presence of nonlinearities, and this effect is seen to decrease as the mode number is increased.

\section{Effects of Pretwist, Coriolis Forces and Geometric Nonilnearities}

The individual and combined effects of pretwist, precone, Coriolis forces and thickness ratio on the frequencies of rotating blades in the absence of geometric nonlinearities were presented and discussed in reference 10 . However. the linear frequencles are presented again in all the following ables for the purpose of completeness, and also to provide an easy access fo. discussing all the results together. The slight differences (at the lourth 
signiflcant flgure) sne may find between the linear frequencles oresanted in this paper and those in reference 10 are due to the fact that the extensional degree of freedom was ignored in reference 10 while this degree of freedom is included in this work, and also due to the fact that the methods of solution used in these two works are different.

In order to ascertain the individual and combined effects of precone, rotational speed, Corlolis forces and the various terms that arise in the equations due to the inclusion of second degree geometric nonilinearities, several cases rotating blades were solved. These results are presented in tables VI and YII for both untwisted and $30^{\circ}$ pretwisted blades having zero collective pitch $\left(\varphi=0^{\circ}\right)$. Typical rotational parameter values of $\left(\Omega / \omega_{1}\right)=0.5$, 0.8 and 1.0 were corisidered in this study since these vaiues generally encompass the practical operational speeds of advanced turboprop biades. The frequency parameter ratios $\left(p / \lambda_{1}\right)$ obtained from the solution of the linear equations. including or excluding the Corfolis effects, are presented first in these tables. Next, the frequencles obtained from the perturbation solution of the nonlinear equations are presented, starting with the frequencies of full nonitinear equations followed by those obtained by ignoring one key parameter in the nonlinear equations at one time. Thus, the frequency parameters under the column with $A_{i j k}=0$ represent the frequencles obtained by finoring the foreshortening effects although all other effects are present, those under the column with $\left(D_{1 j k}=0, E_{1 j k}=0\right)$ illustrate the ef ject of ignoring the nonlinear terms arising from the centrifugal tension terms $\left(\left(T w^{\prime}\right)^{\prime}\right.$ and $\left.\left(T v^{\prime}\right)^{\prime}\right)$, whlle the frequencles in the last column indicate the effect of ignoring the nonilnear terms assoclated with the extensional deformation together with thcse from centrifugal tensions. While the results presented in this form are useful for future comparison, the individual effects will be clearer if percent varlation of the frequencies are calculated for each category based on full nonlinear solutions. This is accomplished in tables VIII and IX. The following observations can be made from the results presented in these tables:

1. The limiting values of precone of zero and $90^{\circ}$ are considered first on the vitrational characteristics. When $B p_{C}=0$, one can see from equations (9) to (10) that the flap-lag equations are coupled through the nonlinear Corlolis force terms together with the linear and nonlinear extensional deformation coupling terms. Coupling due to the latter category of terms is not that important however. Pretwist in the blade brings in the additional important structural coupling between flap and lag deflections. Thus, for untwisted and pretwictad blades, the effects of geometric nonilinearities (excepting for the Corlolls terms which are important for thick blades) on thie natural frequencles is almost negligible when precone is zero. When the precone is $90^{\circ}$. the flap and the lag equations are coupled through linear cortolis force terms and extensional inerila even for the untwisted case, while the extensional equaticn of motion is coupled through the inertia assoclated with foreshortening. Since the right hand side for this case of $90^{\circ}$ precone is zero for all the coupled equations, the steady state deformations will be absent, and the equations produce results that depend only on Corlolis effects. This can be verlfied from the results presented in table VI(a) for $90^{\circ}$ precone case. The effects of geometric nonilinearities and linear and nonlinear Cortolis forces are therefore important for precone angles other than these extremes.

2. Although the frequencles show both increasing and Jecreasing trends for a given precone with an increase in rotational speed, (refer to table VI(a)), the effect of geometric nonilinearities is seen to increase the frequencles of 
flatwise modes, and to decrease the frequency of first edgewise mode (refer tables YIII and IX) for untusteted and protusteted blados for the practica! rotor speeds considered

3. The effect of second degree geometric nonlinearifies is the greatest on the fundamental mode, and decreases as the mode number is increased. The effect of second degree geometric nonllieailties increases as the rotational speed is increased. By referring to tables VII(a) and (b), it can also be seen that an increase in precone from $15^{\circ}$ to $45^{\circ}$ increases the effect of the geometric nonlinear terms considerably for a given rotatinnal speed.

4. In tables VIII and $I X$, the percent frequency variation due to the absence of linear or nonlil:ear corlolis effect terms in the presence the other and with second degree geometric nonlinearities is presented. These frequency varlations are calculated based upon full nonlinear frequencies. It can be seen from these results that the nonlinear Cortolis effects are stronger inan the linear ones in affecting the frequencles of all modes for high rotational speeds generally. Both hardening and softening characteristics are exhibited by the linear and nonlinear coriolis terms for a given mode with increasing rotational speed. This trend is to be attributed to the fact that even though the linear (or nonlinear) Corlo11s terms are ignored and nonlinear (or linear) Coriolis terms are retained in the equations, the presence of other geometric nonlinearities also affect the resulting frequencies which causes these mixed trends. It emergas clearly, however, that both linear and nonlinear coriolis effects are important for high thickness ratio untwisted or pretwistec biades, and these effects are insignificant for low thickness ratio blades. For the cases where the Corlolis effects are important, the 1+near Corlolis effects oppose the nonlinear corlolis effects. The inflience of the linear and nonlinear Coriolis effects are the greatest on the first flatwise mode and on the first edgewise mode, and are insignificant on other higher modes. These effects are more pronounced for larger precones and higher rotational speeds. One may thus conclude that both linear and nonlinear corlolis effects can be ignored in analyzing thin blades which are tyolcal of advanced turboprop blade configurations.

5. The effects of ignoring elther the foreshortening terms, or the centrifugal tension coupling terms on the nonlinear frequencies are shown in the last two columns of tables VIJI and $I X$. It can je seen from these results that these two effects prodice the greatest variations on the frequencies, and that the first mode is affecied to the gratest cxtent. It may also be noted that these terms arise due to the presence of prernne, and the frequency increases by nearly 20 percent due to the presence of the second degree geometric nonlinear terms.

6. The onset of static instablitity for varlous cases of preconed rotating blades with and withuut pretwist was predicted by using the linear equatioris in reference 10 . It was shown that a $60^{\circ}$ preconed blade with a thickness ratio of 0.05 become, statically unstable for $1.48 \leq(\Omega / \omega\rceil) \leq 1.49$ if linear equations including Corlolis effects were used for the prediction of the instablilty. By using the present second degree geometric nonlinear equations with Corlolis effects, this instabllity was found to occur for $1.13 \leq(\Omega / \omega) \leq$ 1.14 for an untwisted blade, and for a $30^{\circ}$ pretwisted blade. When the untwisted thin blade with $60^{\circ}$ precone was solved by using MSC NASTRAN, it was observed that the pseudo-.static configuration became unstable at $\left(\Omega{ }^{\prime} \omega\right)=0.8$. since the results from the analysis using MSC NASTRAN gave consistently good 
agreement of frequencies up to the lowest three modes with the corresponding ones from the present deam tileury inciuding second degree geometric non-

ilnearities, it is belleved that the torsional coupling (which is present in MSC NASTRAN andysis but absent in beam theory) must have been responsible for predicting a lower instablility value. It thus appears that the torsional coupling must be included in the beam theory for a falr prediction of instablitity boundaries.

7. The effect of pretwist in coupling the modes of preconed rotating since the second degree geometric nonlinearities and the nonifinear cortulis effects have not affected the higher modes 'o any great extent as to alter the coupling trends for thin blades. The weli established coupling trend of decreasing the lowei frequency (first edgewtse mode frequency) and increasing the higher frequency (second flatwise mode fraquency) of the two closer modes of untwisted blade due to pretwisting is evident in the results presented in tables VIII(a) and (b) for the thick blade case, for the precones and rotational speeds considered. The effects of second degree geometric nonilinearitles and Coriolis forces on the frequencles of pretwisted blades are similar to those observed for untwisted blade cases.

8. Frequency parameter ratios for $90^{\circ}$ setting ang?e were also determined from the present linear and nonlinear equations. It was found that for a thin from the present linear and nonlinear equaticns.
blade $(d / b=0.05)$, having $B P C=45^{\circ}$ and $(\Omega / \omega)=1.0$, the non inear frequen-
cles of the lowest three mades were greater than the respective linear frequencles by about $0.067,0.005$ and 0.002 percent. These frequency variations for a thick blade $(d / b=0.25)$ were of the order of $1.979,-0.263$ and 0.137 percent respectively. By comparing these results with those obtained for the zero setting anige case $\left(\varphi=0^{\circ}\right)$ presented in table VIII(b), one can conclude that the effects of geometric noninearities are far more severe for $\varphi=0^{\circ}$ than for $\varphi=90^{\circ}$. Results pertaining to $\varphi=90^{\circ}$ for pretwisted blades also show sim:iar trends to those observed for the untwisted case discussed ahove. For brevity these results are not presented. Since it has been established that the geometric nonlinearities and Coriolis forces affect the fundanental mode most severely, it is felt desirable to present the variation of the fundamental mode frequency parameter ratio with respect to the variation of precone for various combinations of setting angle and pretwist. This is shown in figure 3. It can be seen from this figure that for a given rotational speed and precone, the variation of pretwist changes che fundamental mode frequency to an appreciable extent for setting angle $\varphi$ of around $45^{\circ}$. While the fundamental mode frequency is quite distinct and well separated for each combination of setting angle and pretwist at cero degree precone, these frequency values droop down to a small zone at $90^{\circ}$ precone. Since for $B P C=90^{\circ}$, $t:$ : nreconed blade becomes a cantilevered shaft, the effect of setting angle vanislies, and the slight difference observed in the frequency values mist be attributed to the coupling effects arising from pretwist and the linear corlolis terms. Finaliy, resulis were obtained for the various cases discussed earlier by ignorilig the extensional deformation. The differences observed were in the fourth or fifth significant figure as compared to the corresponding flap-lag-extensional equations' solution. For the geometric and physical parameters considered in this work, the extensional degree of freedom can thus be safely ignored. It is also observed that the mode shapes calculated about the deformed equilibrlum position and obtained by using the present nonitinear equations do not differ to any appreciable extent from those obtained from the ilnear theory. 


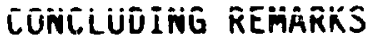

Coupled flap-lag-extensional equations of motion of rotating, pretwisted cantllever blades of untform rectangular cross section are derived including large precone, Corlolis effects and second degree geometric nonilinearities. Parametric studies are conducted io assess the individual and combined influence of the various complicating effects by solving the nonlinear equations using a linear pertubation technique. The following major conclustons have emerged from the present effort:

1. Inclusion of the geometric nonisnearities up through second degree only in the flap-lag-extension equations appears to be adequate for the prediction of steady-state deflections and the first few natural frequencies (if they are well separated from a basic torsional frequency) of thin blades having precones of up to $45^{\circ}$, and rotating at speeds of the order of $\Omega / \omega \gamma=1.0$.

The second degree geometric nonlinearities show a stiffining effect on the flatwise modes in general, and a softening effect on the first edgewise mode, for precones of up to $50^{\circ}$ and for all rotational speeds considered in this work. The effect of geometric nonlinearities on higher modes is not significant. The greatest effect is from those nonilinear terms which vanish for zero precone. However, if precone is substantlal, the second degree nonlinear terms can produce frequency changes of engineering significance. The increase in frequencles of first flatwise and first edgewise modes are typically of the respective orciers of +20 percent and -4 percent for blades with $45^{\circ}$ precorie and for a rotational speed parameter of $\Omega / \omega\rceil=1.0$.

2. The effect of nonlinear Corlolis forces is most severe on the first flatwise and first edgewise modes, and insignificant on higher modes. The effect of Cortolis forces is found to be significant for thick blade cases. In general, the nonlinear Corlolls forces oppose the linear ones, the nonlinear effect being stronger. Thus, both linear and nonlinear coriolis effects can be ignored in analyzing thin blades which are typical of advanced turboprop blade configurations.

3. Preconing has significant influence on the first flatwise and edgewise modes. An increase in precone at a given rotational speed shows a softening effect on flatwise modes generally, and a stiffening effect on the first edgewise mode. However, the softening effect is much more pronounced than the stiffening effect.

4. The coupling trends for pretwisted blades observed from the solution of the present nonilinear equations, do not differ to any appreciable extent from those obcerved from the linear theory. This may be attributed partialiy to the fact that geometric noninearities do not significantly affect higher modes for tlie present flap-lag-extensional equations. 
APPENDIX. A: THE GALERKIN INTEGRALS AND MODEL EQUATIONS

The various integrals arising from the Galerkin process are defined below, and these are used in representing the modal equations in matrix forms subsequently:

$$
\begin{aligned}
& \delta_{i j}=\int_{0}^{1} \psi_{i} \psi_{j} d n=\int_{0}^{1} \theta_{1} \theta_{j} d n \\
& A_{1 j k}=\int_{0}^{1} \psi_{f} \int_{0}^{\eta_{1}} \psi_{j}^{\prime}(\bar{x}) \psi_{k}(\bar{x}) d \bar{x} d \eta \\
& B_{1 j}=\int_{0}^{1} \psi_{i} \psi_{j} 0 d \eta \\
& c_{1 j}=\int_{0}^{1} \psi_{1} \psi_{j}^{\prime} S d \eta \\
& D_{i j k}=\int_{0}^{1} \psi_{1} \psi_{j}^{\prime \prime} \int_{\eta}^{1} \Psi_{k}(\bar{x}) d \bar{x} d \eta \\
& E_{1 j k}=\int_{0}^{1} \psi_{1} \psi_{j}^{\prime \prime} \psi_{k} d n \\
& F_{i j}=\int_{0}^{l} \psi_{1} \psi_{j}^{i v}\left(\cos ^{2} \theta+\frac{b^{2}}{d^{2}} \sin ^{2} \theta\right) d n \\
& G_{1 j}=\int_{0}^{T} \psi_{1} \psi_{j}^{\prime \prime \prime} \sin 2 \theta d n \\
& H_{1 j}=\int_{0}^{1} \psi_{1} \psi_{j}^{\prime \prime} \cos 2 \theta d n \\
& I_{1 j}=\int_{0}^{1} \psi_{1} \psi_{j}^{i v} \sin 2 \theta d n \\
& J_{1 j}=\int_{0}^{\prime} \psi_{1} \psi_{j}^{\prime \prime} \cos 2 \theta d \eta \\
& k_{1 j}=\int_{0}^{1} \psi_{f} \psi_{j}^{\prime \prime} \sin 2 \theta d \eta
\end{aligned}
$$

15 


$$
\begin{aligned}
& L_{1}=\int_{0}^{1} \Psi_{1} n d \eta \\
& M_{i j}=\int_{0}^{\pi} \psi_{i} \psi_{j}^{i v}\left(\sin ^{2} \theta+\frac{b^{2}}{d^{2}} \cos ^{2} \theta\right) d \eta \\
& N_{1 j}=\int_{0}^{1} \psi_{1} \psi_{j}^{\prime \prime} d \eta \\
& o_{i j}=\int_{0}^{1} \psi_{i} \theta_{j} t_{n} \\
& P_{i j k}=\int_{0}^{1} \theta_{k} d \eta \int_{0}^{1} \psi_{1} \psi_{j}^{\prime \prime} d \eta-\int_{0}^{1} \psi_{i} \psi_{j}^{\prime \prime} \int_{0}^{n} \theta_{k}(\bar{x}) d \bar{x} d \eta \\
& Q_{1 j k}=\int_{0}^{1} \psi_{j} \psi_{j}^{\prime} \theta_{k} d \eta \\
& R_{1 j}=\int_{0}^{1} \theta_{1} \theta_{j}^{\prime \prime} d \eta \\
& S_{1}=\int_{0}^{1} \theta_{1} n d \eta \\
& T_{1 j k}=\int_{0}^{1} \theta_{1} \int_{0}^{\eta} \psi_{j}^{\prime}(\bar{x}) \psi_{k}^{\prime}(\bar{x}) d \bar{x} d \eta \\
& u_{1}=\int_{0}^{1} \psi_{1} \sin 2 \theta d n \\
& v_{1}=\int_{0}^{1} \psi_{1} \cos 2 \theta d n
\end{aligned}
$$

16 
ORIGINAL PAGE IS
OF POOR QUALITY

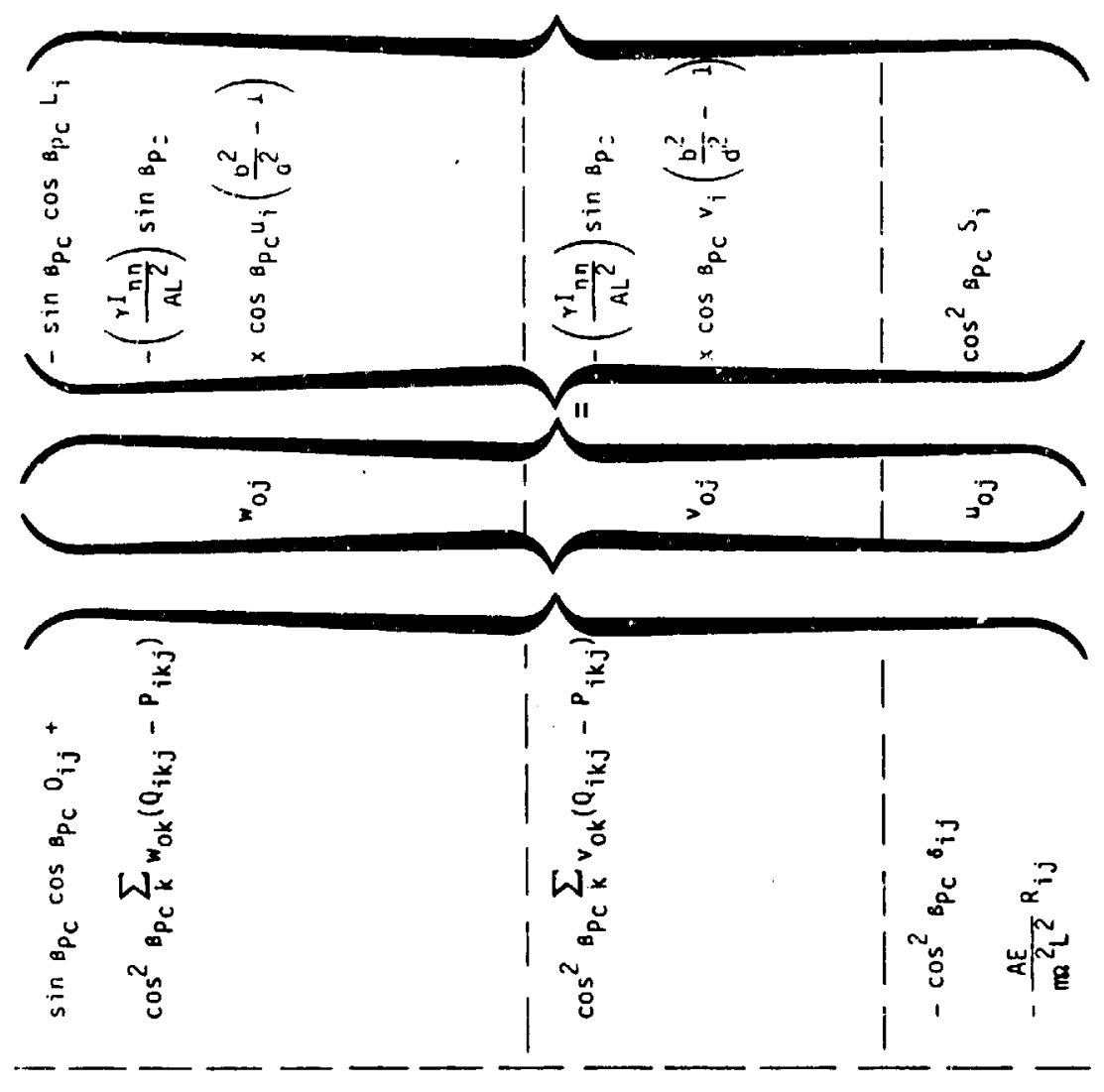

ل्र
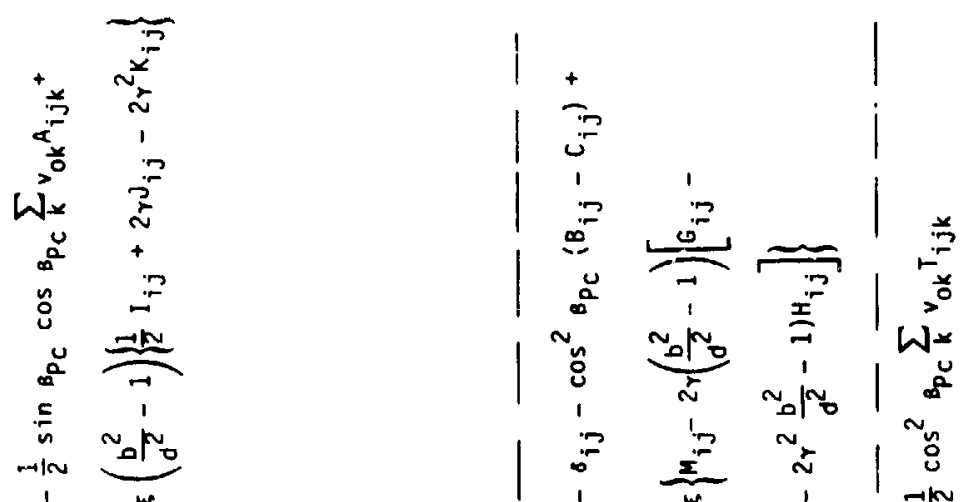

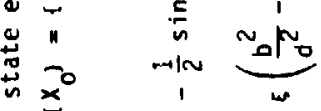

$-$

$\begin{array}{ll}0 & x \\ 0 & 0 \\ 0 & 0 \\ 0 & 0\end{array}$

W.

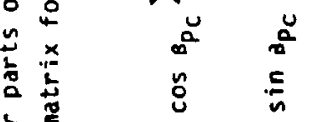

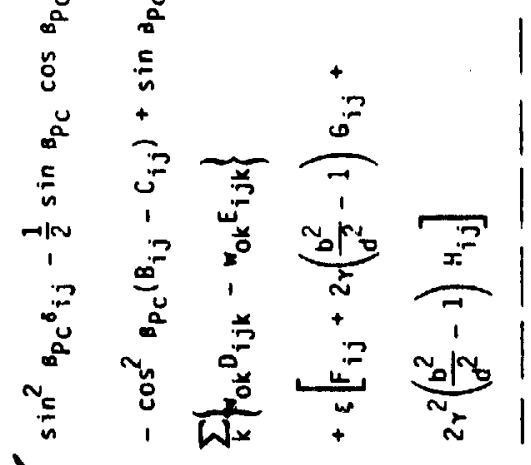

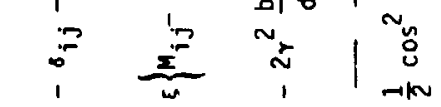

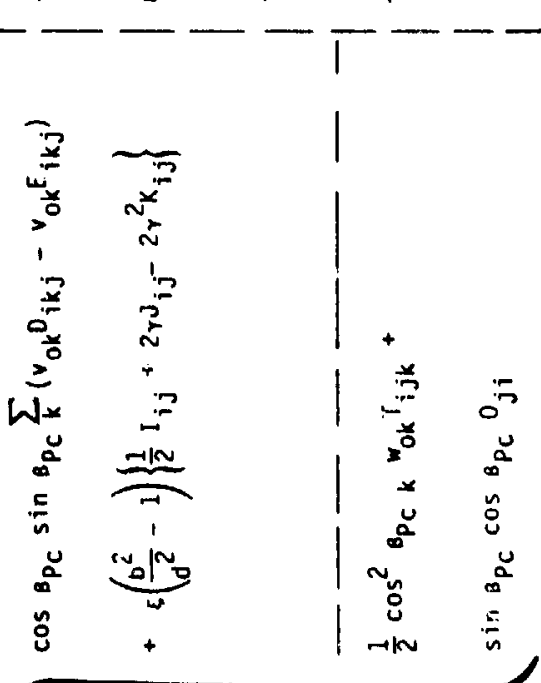




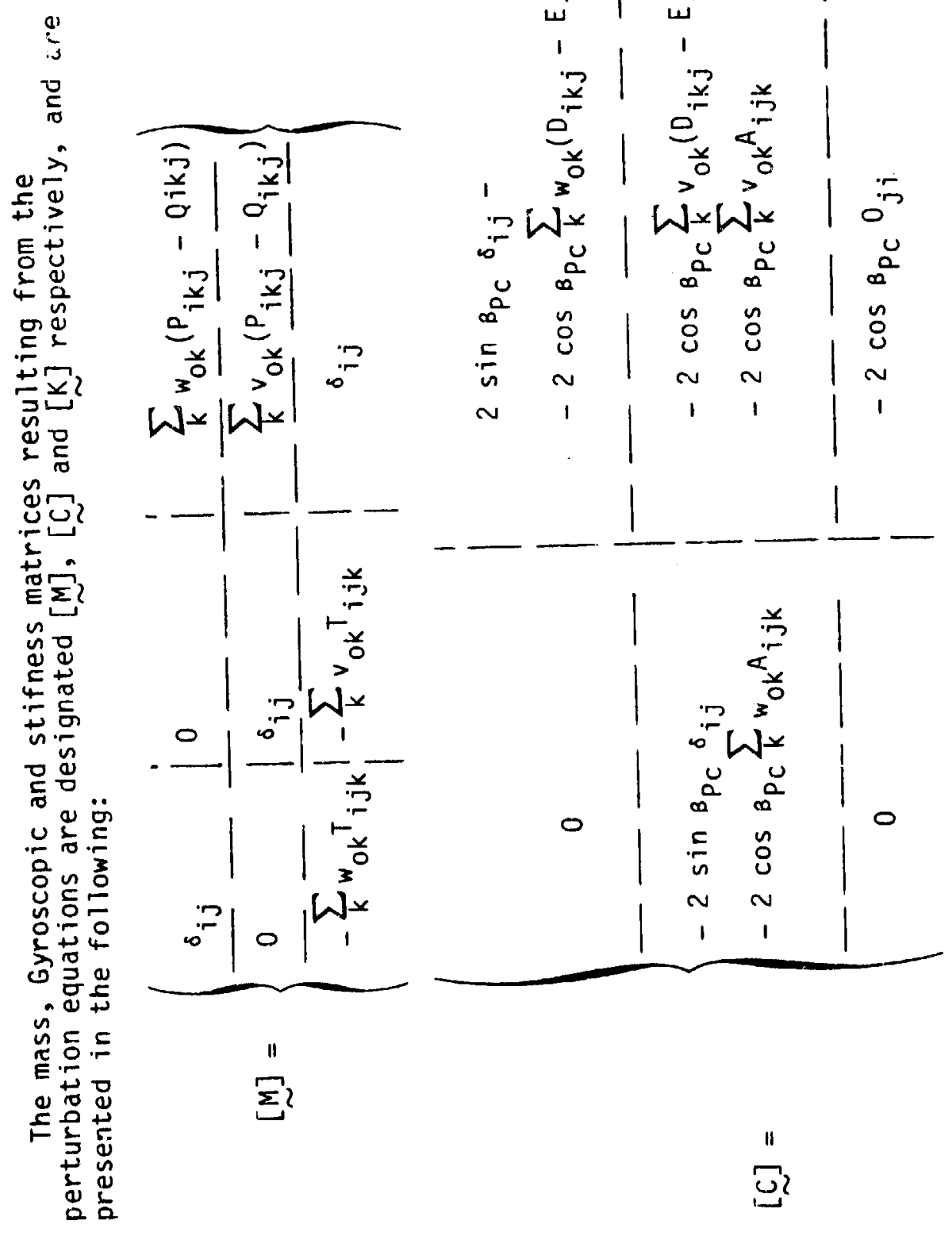




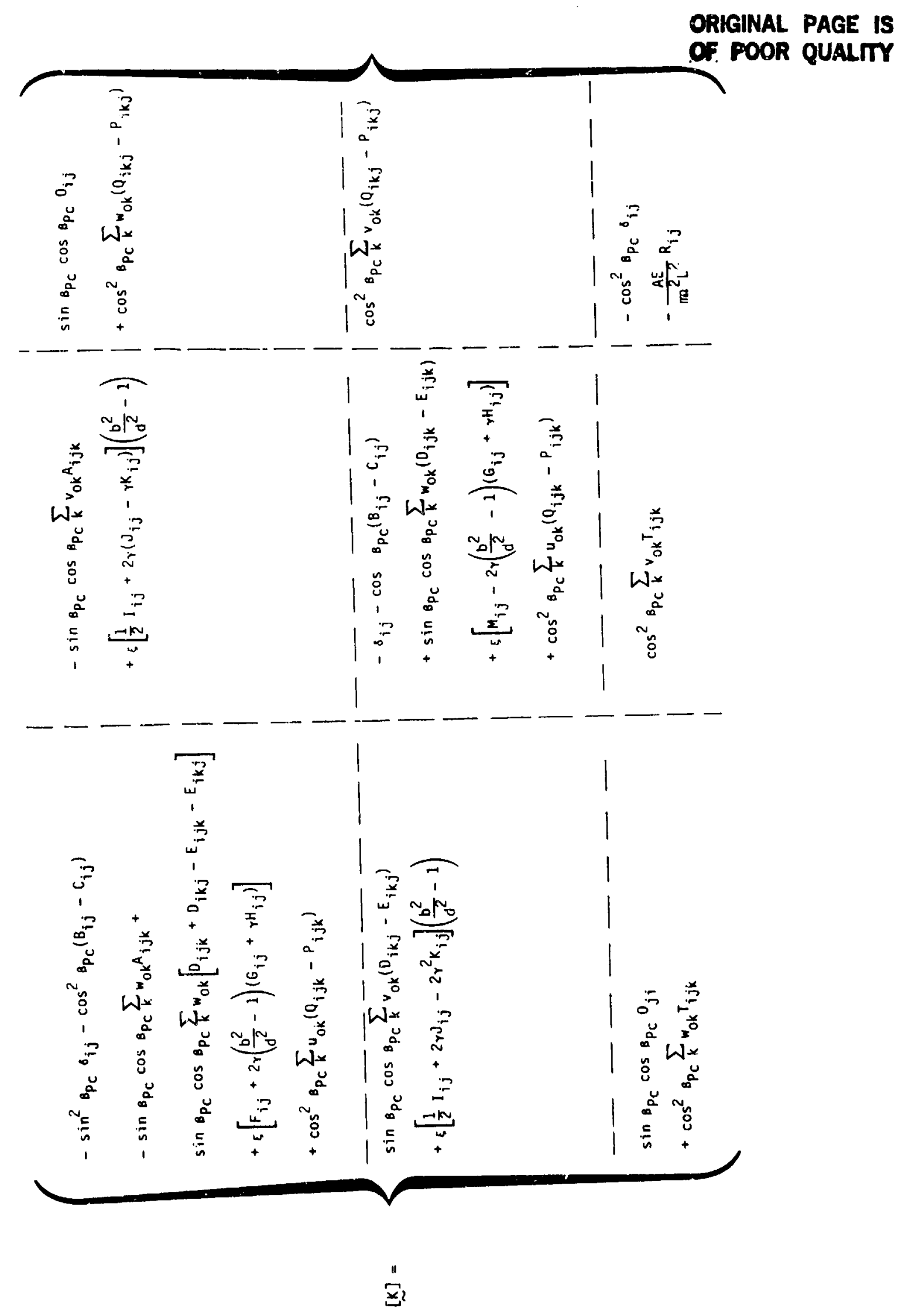




\section{APPCNOIX B - NOHENCLATURE}

A cross-sectional area of blade

$A_{i j k}, B_{\{j}, L_{1}$, etc. modal integrals (see appendix A)

b. d

breadth (chord) and thickness of blade

$d / b$

thickness ratio

$\{B\},\{X\},\left\{x_{0}\right\}$

vectors

$[\underset{\sim}{c}]$

E

$I_{\eta \eta}, I_{\xi \xi}$

$1, j, k$

L

$[\stackrel{L}{\sim},[\underset{\sim}{L}]$

m

[M]

n

p

$\mathbf{R}$

$T$

$\mathbf{t}$

$u, v, w$

$\bar{u}, \bar{v}, \bar{w}$

$u_{o j}, v_{o j}, w_{o j}$

$\Delta u_{j}, \Delta v_{j}, \Delta w_{j}$ modal damping matrix (gyroscopic matrix)

Young's modulus

area moments of inerita about major and minor principal centroidal axes, respectively

dummy indices

length of beam

Linear and nonlinear components of the matrix representing steady state equilibrium equations

mass of blade per unit length

modal mass matrix

number of nonrotating modes for each of the flap bending, lead-lag bending, and extenstonal deflections

natural radian frequency

radius of disc

blade tension

time

displacements of the elastic axis in $X, Y, Z$ directions, respecifvely

dimensionaless deflections

steady-state equilibrium deflections

perturbation quantities 
x

Y. Z

$a_{j}, B_{j}, Y_{j}$

BPc

$Y$

$\delta_{1 j}$

$\xi$

n

$\theta$

$\lambda)$

$\rho$

$p$

$y(n)$

T

w)

$\boldsymbol{\Omega}$

()$^{\prime}$

$\left({ }^{\circ}\right)$ running coordinate along $X$-axis

centroidal principal axes of beam cross section

constants for assumed mode shapes

precone angle

total pretwist of the blade over its length

Kronecker delta

nondimensional rotational parameter, $E I_{n n} / \rho A L 4 \Omega^{2}$

nondimensional length coordinate, $x / L$

geometric pitch angle, $\varphi+\gamma n$

frequency parameter, $\sqrt{E I_{n \eta} / \rho A^{4}}$

mass density of biade material

setting angle (collective pitch)

nonrotating flap and lead-lag bending mode shapes

dimensionless time, st

exact fundamental mode frequency of straight, nonrotating beam, $3.51602 \lambda_{1}$

rotor blade angular veloctty, rad/sec

primes denote differentiation with respect to $x$ or $n$

dot over a parameter represents differentiation with respect to $t$ or $t$ 


\section{RFFFRFNCFS}

1. Rao, J.S.: Turbomachine Blade Vibration. Shock and Vibration Digest, vol. 15, no. 5, May 1983, pp. 3-9.

2. Leissa, A.: Vibrational Aspects of Rotating Turbomachinery Biades. Appl. Mech. Rev., vol. 34, no. 5, May 1981, pp. 629-635.

3. Friedmann, Peretz P.: Recent Developments in Rotary - Wing Aeroelasticlty. J. Afrcr., vol. 14, no. 11, Nov. 1977, pp. 1027-1041.

4. Houbolt, John C.; and Brooks, George W.: Differential Equations of Motion for Combined Flapwise Bending, Chordwise Bending, and Torsion of Twisted Nonuniform Rotor Blades. NACA Report 1346, 1958.

5. Carnegle, W.: A Note on the Application of the Vartational Method to Derive the Equations of Dynamic Motion of a Pretwisted Cantilever Blade Mounted on the Periphery of a Rotating Disc Allowing for Shear Deflection, Rotary Inertia and Torsion Bending. Bulletin Mechanical Engineering Education, vol. 5, 1966, pp. 221-223.

6. Subrahmanyam, K.B.; Kulkarn1, S.V.; and Rav, J.S.: Application of the Reissner Method to Derive the Coupled Bending-Torsion Equations of Dynamic Motion of Rotating Pretwisted Cantilever Blading with Allowance for Shear Deflection, Rotary Inertia, Warping and Thermal Effects. J. Sound Vibr., vol. 84, no. 2, Sept. 22, 1982, pp. 223-240.

7. Hodges, O.H.; and Dowe 11, E.H.: Nonlinear Equations of Motion for the Elastic Bending and Torsion of Twisted Nonunfform Rotor Blades. NASA TN-D-7817, 1974.

8. Rosen, A.; and Frtedmann, P.P.: Nonlinear Equations for Elastic Helicopter or Wind Turbine Blades Undergoing Moderate Deformation. University of Calffornia, Los Angeles, School of Engineering and Appiled Science Report, UCLA-ENG-7718, Dec. 1978.

9. Kaza, K.R.V.; and Kvaternik, R.G.: Nonlinear Aeroelastic Equations for Combined Flapwise Bending, Chordwise Bending, Torsion and Extension of Twisted Non-Uniform Rotor Blades in Forward Filght. NASA TM-74059, 1977.

10. Subrahmanyam, K.B.; and Kaza, K.R.V.: Vibration and Buckling of Rotating, Pretwisted, Preconed Beams Including Corlolis Effects. MASA TM-87004, 1985. (To be presented at the 10th Biennial ASME Uesign Engineering Conference and Exhibit on Mechantcal Vibration and Notse, Cincinnati, $\mathrm{OH}$, Sept. 10-13, 1985.)

11. Kvaternik, R.G.; White, W.F.; and Kaza, K.R.V.: Nonlinear Flap-Lag-Axtal Equations of a Rotating Beam with Arbitrary Precone Angle. AIAA Paper 7 - $491,1978$.

12. Chang, Tish-Chun.; and Craig, R.R., Jr.: On Normal Modes of Uniform Beams. Engineering Mechanics Research Laboratory, Untversity of Texas, EMRL 1068, 1969. 
13. The International Mathematical and Statistical Library (IMSL). Houston, TX, Edition 9, Revision, June 1, 1982.

14. Leissa, A.: and Co, C.: Coriolis Effects on the Vibration of Rotating Beams and Plates. Proceedings of XII SECTAM Conference, Callaway Gardens, Vol. II, Auburn University, AL, 1984, pp. 508-513. 
IABLE I. - CONVERGENCE PATTERN OF FREQUENCY RATIOS $\left(p / \lambda_{1}\right)$

OF A PRECONED, ROTATING BEAM PRODUCEO BY THE GALERKIN

METHOD WITH NONROTATING MORMAL MODES

$\left[\Omega / w 1=0.5, B P_{C}=30^{\circ}, d / b=0.5, L / d=20, \ldots 0^{\circ}\right.$, $\gamma=R=0$.

(a) Frequencies from solution of linear equations lgnoring Coriolis effects

\begin{tabular}{|l|r|r|r|r|r|}
\hline Mode & \multicolumn{1}{|c|}{$n=1$} & \multicolumn{1}{c|}{$n=2$} & $n-3$ & $n=4$ & \multicolumn{1}{c|}{$n=5$} \\
\hline 1 & 3.788724 & 3.788037 & 3.787921 & 3.787906 & 3.787903 \\
2 & 7.008871 & 7.008777 & 7.008761 & 7.008758 & 7.008758 \\
3 & 108.883020 & 22.355387 & 22.355386 & 22.355314 & 22.355303 \\
4 & - & 44.204056 & 44.204056 & 44.204047 & 44.204045 \\
5 & - & 108.882980 & 62.025490 & 62.025447 & 62.025401 \\
\hline
\end{tabular}

(b) Frequencies from solution of linear equations including Cortolis effects

\begin{tabular}{|l|c|r|r|r|r|}
\hline 1 & 3.6 .5308 & 3.634662 & 3.634553 & 3.634539 & 3.634535 \\
2 & 7.302023 & 7.301872 & 7.301851 & 7.301849 & 7.301848 \\
3 & 108.92232 & 22.331668 & 22.331666 & 22.331595 & 22.331584 \\
4 & - & 44.247993 & 44.247881 & 44.247870 & 44.247867 \\
5 & - & 108.92610 & 62.017091 & 62.017049 & 62.017003 \\
\hline
\end{tabular}

(c) Frequencies from perturbation solution of nonlinear

equations: Coriolis effects ignored

\begin{tabular}{|l|r|r|r|r|r|}
\hline 1 & 3.247417 & 2.846369 & 3.846218 & 3.846199 & 3.845194 \\
2 & 7.013543 & 7.019438 & 7.019422 & 7.019420 & 7.019419 \\
3 & 109.47317 & 22.378138 & 22.378096 & 22.378012 & 22.377999 \\
4 & - & 44.213271 & 44.213273 & 44.213263 & 44.213262 \\
5 & - & 109.57995 & 61.959160 & 61.958438 & 51.958267 \\
\hline
\end{tabular}

(d) Frequencies from perturbation solution of nonlinear equations: Coriolis effects includec

\begin{tabular}{|l|c|r|r|r|r|}
\hline 1 & 3.742021 & 3.740674 & 3.740498 & 3.740475 & 3.740470 \\
2 & 7.214380 & 7.214485 & 7.214484 & 7.214484 & 7.214484 \\
3 & 109.51676 & 22.363212 & 22.363188 & 22.363103 & 22.363090 \\
4 & - & 24.242350 & 44.241858 & 44.241828 & 44.241822 \\
5 & - & 109.62655 & 61.954879 & 61.954157 & 61.953988 \\
\hline
\end{tabular}

TABLE 11. - COMPARISON OF FREQLENCY PARAMETER RATIOS, ( $\left.f=p / \lambda_{1}\right)$, OF ROTATING bladeS FROM BEAM THEORY AND MSC NASTRAN

$\left[B \mathrm{PC}=\mathrm{Y}=0^{\circ},(\mathrm{d} / \mathrm{b})=0.05.\right]$

\begin{tabular}{|c|c|c|c|c|c|c|c|c|c|}
\hline$\frac{a}{\omega 1}$ & $\begin{array}{l}\text { Mode } \\
\text { (a) }\end{array}$ & $\begin{array}{c}\text { MSC } \\
\text { NASTRAN }\end{array}$ & $\begin{array}{l}\text { Beann } \\
\text { theory } \\
\text { (non- } \\
\text { linear) }\end{array}$ & $\begin{array}{c}\text { Percent } \\
\text { frequency } \\
\text { difference }\end{array}$ & $\frac{a}{w_{1}}$ & $\begin{array}{l}\text { Mode } \\
\text { (a) }\end{array}$ & $\begin{array}{c}\text { MSC } \\
\text { NASTRAN }\end{array}$ & $\begin{array}{l}\text { Beam } \\
\text { theory } \\
\text { (non- } \\
\text { linear) }\end{array}$ & $\begin{array}{l}\text { Percent } \\
\text { frequency } \\
\text { difference }\end{array}$ \\
\hline 0.5 & $\begin{array}{l}F 1 \\
F 2 \\
F 3 \\
T 1 \\
S 1 \\
F 4 \\
F 5 \\
T 2\end{array}$ & $\begin{array}{r}3.5463 \\
22.1496 \\
61.9732 \\
68.3947 \\
69.9391 \\
121.4804 \\
201.0141 \\
206.2487\end{array}$ & $\begin{array}{r}3.5213 \\
22.0390 \\
61.7017 \\
70.3203 \\
120.9065 \\
199.8640 \\
\end{array}$ & $\begin{array}{c}0.705 \\
0.499 \\
0.438 \\
-0.545 \\
0.472 \\
0.572 \\
- \\
-\end{array}$ & 1.00 & $\begin{array}{l}F 1 \\
F 2 \\
F 3 \\
71 \\
51 \\
F 4 \\
F 5 \\
T 2\end{array}$ & $\begin{array}{r}5.2142 \\
23.8828 \\
63.7103 \\
68.5803 \\
69.9556 \\
123.2737 \\
202.8394 \\
206.5022\end{array}$ & $\begin{array}{r}5.1917 \\
23.7831 \\
63.4591 \\
70.3359 \\
122.7303 \\
201.7327 \\
\end{array}$ & $\begin{array}{r}0.432 \\
0.418 \\
0.394 \\
-0.544 \\
0.441 \\
0.546 \\
\end{array}$ \\
\hline 0.50 & $\begin{array}{l}F 1 \\
F 2 \\
F 3 \\
11 \\
51 \\
144 \\
F 5 \\
12\end{array}$ & $\begin{array}{r}4.0287 \\
22.5920 \\
62.4092 \\
68.4408 \\
69.9432 \\
121.9282 \\
201.4689 \\
206.3116\end{array}$ & $\begin{array}{r}4.0049 \\
22.4843 \\
62.1428 \\
70.3242 \\
121.3618 \\
200.3292 \\
\end{array}$ & $\begin{array}{r}0.591 \\
0.477 \\
0.427 \\
-0.545 \\
0.465 \\
0.566 \\
- \\
-\end{array}$ & 1.20 & $\begin{array}{l}F 1 \\
F 2 \\
F 3 \\
T ! \\
S 1 \\
F 4 \\
F 5 \\
T 2\end{array}$ & $\begin{array}{r}5.7917 \\
24.6085 \\
64.4601 \\
68.6620 \\
69.9629 \\
124.0553 \\
203.6387 \\
206.6139\end{array}$ & $\begin{array}{r}5.7694 \\
24.5132 \\
64.2176 \\
-70.3428 \\
123.5262 \\
202.5524 \\
-\end{array}$ & $\begin{array}{r}0.385 \\
0.387 \\
0.376 \\
-0.543 \\
0.427 \\
0.534 \\
-\end{array}$ \\
\hline 0.80 & $\begin{array}{l}F 1 \\
F 2 \\
F 3 \\
T 1 \\
51 \\
F 4 \\
F 5 \\
T 2\end{array}$ & $\begin{array}{r}4.6850 \\
23.2721 \\
63.0895 \\
68.5134 \\
63.9497 \\
122.6299 \\
202.1829 \\
206.4108\end{array}$ & $\begin{array}{r}4.6621 \\
23.1687 \\
62.8310 \\
70.3303 \\
122.0756 \\
201.0600 \\
\end{array}$ & $\begin{array}{r}0.489 \\
0.444 \\
0.410 \\
-0.544 \\
0.452 \\
0.555 \\
- \\
\end{array}$ & 1.50 & $\begin{array}{l}F 1 \\
F 2 \\
F 3 \\
T 1 \\
S 1 \\
F 4 \\
F 5 \\
72 \\
\end{array}$ & $\begin{array}{r}6.7182 \\
25.8909 \\
65.8156 \\
68.8120 \\
69.9763 \\
125.4796 \\
205.1007 \\
206.8193 \\
\end{array}$ & $\begin{array}{r}6.6958 \\
25.8031 \\
65.5890 \\
-70.3555 \\
124.9769 \\
204.0542 \\
\end{array}$ & $\begin{array}{r}0.333 \\
0.339 \\
0.344 \\
-0.542 \\
0.401 \\
0.510 \\
-\end{array}$ \\
\hline
\end{tabular}

aF 1 , F2,.. F5 are frequencles in flatwise direction; 51 is first edgewise frequency and $T$ and $T 2$ are the lavest two torstonal mode frequencias respectively.

borcent frequency difference. (fNASTRAN - f Nonlinear) x100/f MASTRAN. 
TABLE III. - COMPARISON OF LINEAR AND PERTURBATION FREQUENCIES OF DQFTONFD BLADE AT VARIOUS ROTATIONAL SPEEDS

$\left[B P_{C}=15^{\circ} \ldots R=0\right.$, Thickness ratio $\left.=0.05.\right]$

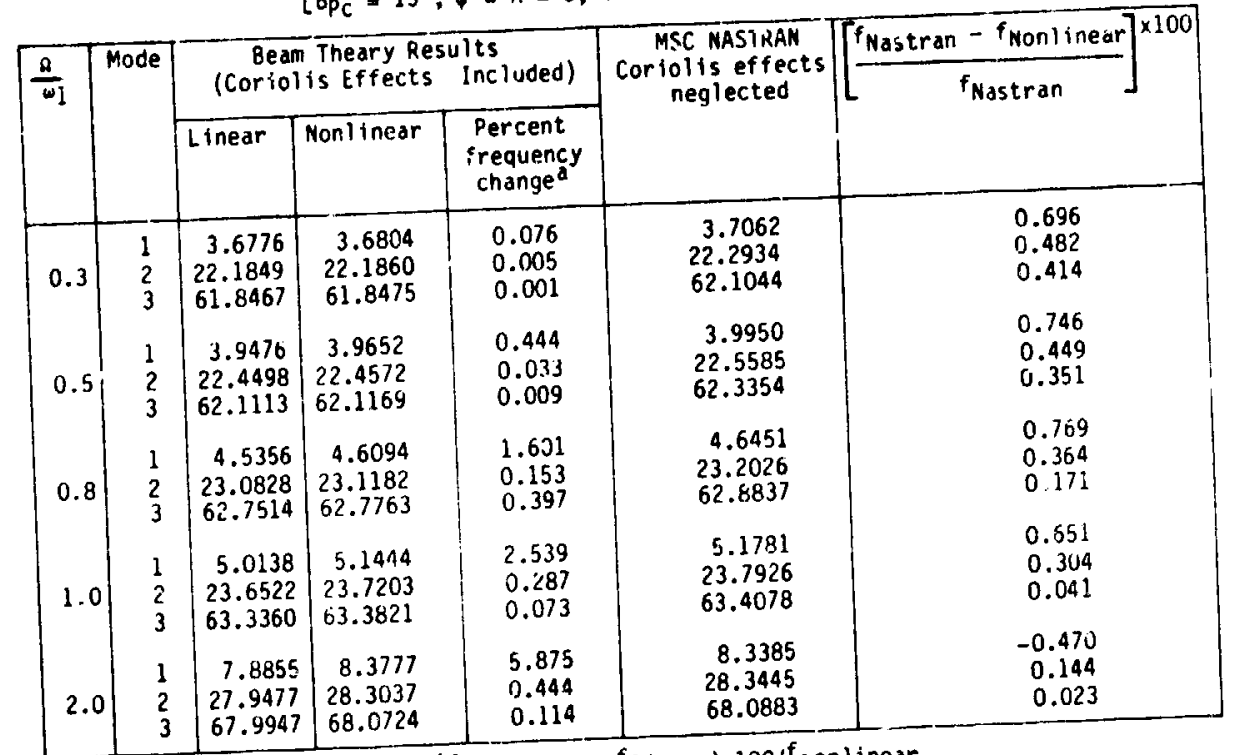

apercent frequency change $=\left(f_{\text {nonlinear }}-f_{1 \text { inear }}\right) \times 100 / f_{\text {ion }}$ inear.

TARLE IV - FURTHER COMPARISON OF FREQUENCY PARAMETER RATIOS, $\left(f=p / \lambda_{1}\right)$, FROM MSC MASTRAN ANO FROM BEAM THEORY FOR VARIOUS PRECONES, ROTATIONAL SPEEOS AND THICKNESS RATIOS

\begin{tabular}{|c|c|c|c|c|c|c|c|c|c|c|c|c|c|}
\hline$d / b$ & $\begin{array}{l}\mathrm{BPC}_{\mathrm{P}} \\
\text { deg }\end{array}$ & $\frac{\Omega}{-1}$ & Mode & $\begin{array}{c}\text { MSC } \\
\text { NASTRAN }\end{array}$ & $\begin{array}{l}\text { Beam } \\
\text { theory }\end{array}$ & $\begin{array}{c}\text { Percent } \\
\text { frequency } \\
\text { difference }\end{array}$ & $\mathrm{d} / \mathrm{b}$ & $\begin{array}{l}\text { spc } \\
\text { deg }\end{array}$ & $\frac{\Omega}{w 1}$ & Mode & $\begin{array}{c}\text { MSC } \\
\text { NASTRAN }\end{array}$ & $\begin{array}{l}\text { Beam } \\
\text { theory }\end{array}$ & $\begin{array}{c}\text { Percent } \\
\text { frequency } \\
\text { difference }\end{array}$ \\
\hline$\because .05$ & 30 & 0.9 & $\begin{array}{l}1 \\
2 \\
3\end{array}$ & $\begin{array}{r}4.7719 \\
23.2410 \\
62.4392\end{array}$ & $\begin{array}{r}4.6937 \\
23.2313 \\
62.8783\end{array}$ & $\begin{array}{r}1.639 \\
0.042 \\
-0.703\end{array}$ & 0.05 & 45 & 0.445 & $\begin{array}{l}1 \\
2 \\
3\end{array}$ & $\begin{array}{r}3.6511 \\
22.2438 \\
61.8224\end{array}$ & $\begin{array}{r}3.6066 \\
22.2087 \\
61.8820\end{array}$ & $\begin{array}{r}1.219 \\
0.158 \\
-0.096\end{array}$ \\
\hline 0.05 & 45 & 0.8 & $\begin{array}{l}1 \\
2 \\
3\end{array}$ & $\begin{array}{r}4.2769 \\
22.6971 \\
61.6110\end{array}$ & $\begin{array}{r}4.1026 \\
22.7218 \\
62.3800\end{array}$ & $\begin{array}{r}4.075 \\
-0.109 \\
-1.248\end{array}$ & 0.05 & 45 & 1.0 & $\begin{array}{l}1 \\
? \\
3\end{array}$ & $\begin{array}{r}4.8337 \\
23.1064 \\
61.4499\end{array}$ & $\begin{array}{r}4.6145 \\
23.2047 \\
62.8250\end{array}$ & $\begin{array}{r}4.535 \\
-0.425 \\
-2.238\end{array}$ \\
\hline 0.05 & 45 & 1.05 & $\begin{array}{l}1 \\
2 \\
3\end{array}$ & $\begin{array}{r}4.9615 \\
23.2508 \\
61.6563\end{array}$ & $\begin{array}{r}4.7622 \\
23.3468 \\
62.9538\end{array}$ & $\begin{array}{r}4.017 \\
-0.413 \\
-2.104\end{array}$ & 0.05 & 60 & 0.5 & $\begin{array}{l}1 \\
2 \\
3\end{array}$ & $\begin{array}{r}3.4708 \\
22.2377 \\
62.0111\end{array}$ & $\begin{array}{r}3.3944 \\
22.1264 \\
61.8150\end{array}$ & $\begin{array}{l}2.201 \\
0.501 \\
0.316\end{array}$ \\
\hline 0.25 & 45 & 0.8 & $\begin{array}{l}1 \\
2 \\
3\end{array}$ & $\begin{array}{r}4.2598 \\
12.8590 \\
22.6460\end{array}$ & $\begin{array}{r}4.0236 \\
b 4.1058 \\
14.2623 \\
b_{13} .9954 \\
22.7315 \\
b_{22} 2.7209\end{array}$ & $\begin{array}{r}5.545 \\
b_{3} .615 \\
-10.913 \\
b_{-}-8.837 \\
-0.378 \\
b_{-}-0.331\end{array}$ & 0.25 & 45 & 1.0 & $\begin{array}{l}1 \\
2 \\
3\end{array}$ & $\begin{array}{r}4.8122 \\
12.3085 \\
23.0257\end{array}$ & $\begin{array}{c}4.5128 \\
b_{4} .6185 \\
14.2650 \\
b 13.9808 \\
23.2460 \\
b 23.2040\end{array}$ & $\begin{array}{r}6.222 \\
04.025 \\
-15.896 \\
b_{-}-13.587 \\
-0.957 \\
0-0.774\end{array}$ \\
\hline
\end{tabular}

apercent frequency difference $=\left(f_{\text {NASTRAN }}-f_{\text {nonlinear }}\right) \times 100 / f_{\text {NASTRAN }}$.

bicoriolis effects are included in beam theory in all cases except where marked and are absent in MSC MASTRAN calculations) $=Y=0^{\circ}, R=0$ 


\section{ORIGINAL PAGE IS OF FOOR QUALITY}

TABLE $Y$ - COMPAPISON OF LINEAR AND PURTURBATION FREQUENCIES OF ROTATING BLADES AT VARIOUS PRECONE ANGLES (CORIOLIS EFFECTS INCLUDED):

$\Omega / \omega_{1}=1.0,0=0^{\circ}, \delta^{\circ}=$ ?

\begin{tabular}{|c|c|c|c|c|c|c|c|}
\hline \multirow[t]{2}{*}{ BPC } & \multirow[t]{2}{*}{ Mode } & \multicolumn{3}{|c|}{ Low thickness ratio, $d / b=0.05$} & \multicolumn{3}{|c|}{ High thickness ratio, $d / b=0.25$} \\
\hline & & Linear & Nonlinear & $\begin{array}{l}\text { Percent } \\
\text { frequency } \\
\text { variationa }\end{array}$ & Linear & Nonlinear & $\begin{array}{l}\text { Percent } \\
\text { frequency } \\
\text { variationa }\end{array}$ \\
\hline 10 & $\begin{array}{l}1 \\
2 \\
3\end{array}$ & $\begin{array}{r}5.1124 \\
23.7242 \\
63.4037\end{array}$ & $\begin{array}{r}5.1713 \\
23.7553 \\
63.4246\end{array}$ & $\begin{array}{l}1.139 \\
0.131 \\
0.033\end{array}$ & $\begin{array}{r}5 . n 912 \\
14.1663 \\
23.7219\end{array}$ & $\begin{array}{r}5.1680 \\
14.1229 \\
23.7606\end{array}$ & $\begin{array}{r}1.486 \\
-0.307 \\
0.163\end{array}$ \\
\hline 20 & $\begin{array}{l}1 \\
2 \\
3\end{array}$ & $\begin{array}{r}4.8770 \\
23.5540 \\
63.2440\end{array}$ & $\begin{array}{r}5.1043 \\
23.6709 \\
63.3234\end{array}$ & $\begin{array}{l}4.453 \\
0.494 \\
0.125\end{array}$ & $\begin{array}{r}4.8009 \\
14.2935 \\
23.5450\end{array}$ & $\begin{array}{r}5.0865 \\
1.1313 \\
23.6854\end{array}$ & $\begin{array}{r}5.615 \\
-1.148 \\
0 . j 93\end{array}$ \\
\hline 20 & $\begin{array}{l}1 \\
2 \\
3\end{array}$ & $\begin{array}{r}4.4930 \\
23.2908 \\
62.9985\end{array}$ & $\begin{array}{r}4.9749 \\
23.5282 \\
63.1612\end{array}$ & $\begin{array}{l}9.687 \\
1.009 \\
0.258\end{array}$ & $\begin{array}{c}4.3492 \\
14.477 \\
23.2718\end{array}$ & $\begin{array}{r}4.9316 \\
14.1553 \\
23.5526\end{array}$ & $\begin{array}{r}11.810 \\
-2.273 \\
1.192\end{array}$ \\
\hline 40 & $\begin{array}{l}1 \\
2 \\
3\end{array}$ & $\begin{array}{r}3.9725 \\
22.9639 \\
62.6960\end{array}$ & $\begin{array}{r}4 ., 010 \\
23.3266 \\
i 2.9476\end{array}$ & $\begin{array}{r}16.562 \\
1.555 \\
C .400\end{array}$ & $\begin{array}{r}3.7715 \\
14.6859 \\
22.9329\end{array}$ & $\begin{array}{r}4.6814 \\
14.2072 \\
23.3554\end{array}$ & $\begin{array}{r}19.437 \\
-3.369 \\
1.809\end{array}$ \\
\hline 45 & $\begin{array}{l}1 \\
2 \\
3\end{array}$ & $\begin{array}{r}3.6659 \\
22.7880 \\
62.5344\end{array}$ & $\begin{array}{r}4.61 .45 \\
23.2047 \\
62.8250\end{array}$ & $\begin{array}{r}20.557 \\
1.796 \\
0.463\end{array}$ & $\begin{array}{r}3.4464 \\
14.7907 \\
22.7509\end{array}$ & $\begin{array}{r}4.5133 \\
14.2477 \\
23.2316\end{array}$ & $\begin{array}{r}23.639 \\
-3.811 \\
2.069\end{array}$ \\
\hline 50 & $\begin{array}{l}1 \\
2 \\
3\end{array}$ & $\begin{array}{r}3.3315 \\
22.6109 \\
62.3724\end{array}$ & $\begin{array}{r}4.4371 \\
23.0697 \\
62.6942\end{array}$ & $\begin{array}{r}24.917 \\
1.989 \\
0.513\end{array}$ & $\begin{array}{r}3.1023 \\
14.8916 \\
22.5677\end{array}$ & $\begin{array}{r}4.3129 \\
14.3002 \\
23.0910\end{array}$ & $\begin{array}{r}28.069 \\
-4.136 \\
2.266\end{array}$ \\
\hline
\end{tabular}

apercent frequency variation $=($ unonlinear - wlinear $) \times 100 /$ mononlinear. 
TABLE V1. - ETFECT OF LIMEAR ANO NOM IMEAR CORIOLIS FORCES, AMO VARIOUS NONLIMEAR TERMS OH THE FREQUENCY PARAMETER RATIOS FOR UNTWISTED THIN BLADES

(a) $d / b=0.05, p=0^{\circ}, r=0^{\circ}, \bar{k}=0$

\begin{tabular}{|c|c|c|c|c|c|c|c|c|c|c|}
\hline \multirow[t]{2}{*}{ spc } & \multirow{2}{*}{$\frac{a}{u_{1}}$} & \multirow[t]{2}{*}{ Mode } & \multicolumn{2}{|c|}{ Solution of linear equations } & \multicolumn{6}{|c|}{ Perturbation solution of nonlinear equations } \\
\hline & & & $\begin{array}{l}\text { Coriolis } \\
\text { forces } \\
\text { included }\end{array}$ & $\begin{array}{l}\text { Corialis } \\
\text { forces } \\
\text { Ignored }\end{array}$ & $\begin{array}{c}\text { Full } \\
\text { nonlinear } \\
\text { equation }\end{array}$ & $\begin{array}{l}\text { Linear } \\
\text { Coriolis } \\
\text { forces } \\
\text { ignored }\end{array}$ & $\begin{array}{c}\text { Monl inear } \\
\text { Cortolis } \\
\text { forces } \\
\text { ignored }\end{array}$ & $A_{\text {ijk }}=0^{d}$ & $\begin{array}{l}D_{i j k}=0^{b} \\
\epsilon_{i j k}=0^{b}\end{array}$ & $\begin{array}{l}D_{i j k}=0 \\
E_{i j k}=0 \\
P_{i j k}=O^{C} \\
Q_{i j k}=0^{C}\end{array}$ \\
\hline \multirow{4}{*}{$25^{\circ}$} & 0.5 & $\begin{array}{l}1 \\
2 \\
3\end{array}$ & $\begin{array}{r}3.9476 \\
22.4498 \\
62.1113\end{array}$ & $\begin{array}{r}3.9480 \\
22.4498 \\
62.1114\end{array}$ & $\begin{array}{r}3.9652 \\
22.4572 \\
62.1169\end{array}$ & $\begin{array}{r}3.9654 \\
22.4572 \\
62.1159\end{array}$ & $\begin{array}{r}3.9650 \\
22.4572 \\
62.1173\end{array}$ & $\begin{array}{r}3.9593 \\
22.4563 \\
62.1170\end{array}$ & $\begin{array}{r}3.9535 \\
22.4507 \\
62.1115\end{array}$ & $\begin{array}{r}3.9535 \\
22.4507 \\
62.1117\end{array}$ \\
\hline & 0.8 & $\begin{array}{l}1 \\
2 \\
3\end{array}$ & $\begin{array}{r}4.5356 \\
23.0828 \\
62.7514\end{array}$ & $\begin{array}{r}4.5366 \\
23.0829 \\
62.7515\end{array}$ & $\begin{array}{r}4.6094 \\
23.1182 \\
62.7763\end{array}$ & $\begin{array}{r}4.6096 \\
23.1182 \\
62.7763\end{array}$ & $\begin{array}{r}4.6087 \\
23.1185 \\
62.7807\end{array}$ & $\begin{array}{r}4.5852 \\
23.1142 \\
62.7792\end{array}$ & $\begin{array}{r}4.5608 \\
23.0873 \\
62.7525\end{array}$ & $\begin{array}{r}4.5608 \\
23.0874 \\
62.7531\end{array}$ \\
\hline & 2.0 & $\begin{array}{l}1 \\
2 \\
3\end{array}$ & $\begin{array}{r}5.0138 \\
23.6522 \\
63.3360\end{array}$ & $\begin{array}{r}5.0155 \\
23.6524 \\
63.3361\end{array}$ & $\begin{array}{r}5.1444 \\
23.7203 \\
63.3821\end{array}$ & $\begin{array}{r}5.1443 \\
23.7202 \\
63.3820\end{array}$ & $\begin{array}{r}5.1431 \\
23.7210 \\
63.3936\end{array}$ & $\begin{array}{r}5.1021 \\
23.7131 \\
63.3909\end{array}$ & $\begin{array}{r}5.0589 \\
23.6611 \\
63.3383\end{array}$ & $\begin{array}{r}5.0589 \\
235611 \\
63.3594\end{array}$ \\
\hline & 0.5 & $\begin{array}{l}1 \\
2 \\
3\end{array}$ & $\begin{array}{r}3.5553 \\
22.2252 \\
61.9077\end{array}$ & $\begin{array}{r}3.5576 \\
22.2256 \\
61.9078\end{array}$ & $\begin{array}{r}3.6482 \\
22.2616 \\
61.9351\end{array}$ & $\begin{array}{r}3.698 \\
22.2618 \\
61.9352\end{array}$ & $\begin{array}{r}3.6476 \\
22.2616 \\
61.9364\end{array}$ & $\begin{array}{r}3.6180 \\
22.2574 \\
61.9350\end{array}$ & $\begin{array}{r}3.5872 \\
22.2299 \\
61.9083\end{array}$ & $\begin{array}{r}3.5872 \\
22.2299 \\
61.9094\end{array}$ \\
\hline \multirow[t]{3}{*}{$45^{\circ}$} & 0.8 & $\begin{array}{l}1 \\
2 \\
3\end{array}$ & $\begin{array}{r}3.6141 \\
22.5196 \\
62.2344\end{array}$ & $\begin{array}{r}3.6199 \\
22.5206 \\
62.2348\end{array}$ & $\begin{array}{r}4.1026 \\
22.7218 \\
62.3800\end{array}$ & $\begin{array}{r}4.1050 \\
22.7221 \\
62.3800\end{array}$ & $\begin{array}{r}4.0991 \\
22.7230 \\
62.3976\end{array}$ & $\begin{array}{r}3.9591 \\
22.7050 \\
62.3943\end{array}$ & $\begin{array}{r}3.7994 \\
22.5476 \\
62.2388\end{array}$ & $\begin{array}{r}3.7994 \\
22.5478 \\
62.2448\end{array}$ \\
\hline & 1.0 & $\begin{array}{l}1 \\
2 \\
3\end{array}$ & $\begin{array}{r}3.6659 \\
22.7880 \\
62.5344\end{array}$ & $\begin{array}{r}3.6751 \\
22.7895 \\
62.5349\end{array}$ & $\begin{array}{r}4.6145 \\
23.20<7 \\
62.8250\end{array}$ & $\begin{array}{r}4.6164 \\
23.2045 \\
62.8246\end{array}$ & $\begin{array}{r}4.6069 \\
23.2080 \\
62.8761\end{array}$ & $\begin{array}{r}4.3631 \\
23.1816 \\
62.8784\end{array}$ & $\begin{array}{r}4.0621 \\
228500 \\
62.5451\end{array}$ & $\begin{array}{r}4.0621 \\
22.8504 \\
62.5576\end{array}$ \\
\hline & 0.5 & $\begin{array}{l}1 \\
2 \\
3\end{array}$ & $\begin{array}{r}3.0412 \\
21.9636 \\
61.6719\end{array}$ & $\begin{array}{r}3.0450 \\
21.9643 \\
61.6722\end{array}$ & $\begin{array}{r}3.0412 \\
21.9636 \\
61.6719\end{array}$ & $\begin{array}{r}3.0450 \\
2.1 .9643 \\
61.6722\end{array}$ & $\begin{array}{r}3.0412 \\
21.9636 \\
61.6719\end{array}$ & $\begin{array}{r}3.0412 \\
\bar{c} 1.9636 \\
61.6719\end{array}$ & $\begin{array}{r}3.0417 \\
21.9636 \\
61.6719\end{array}$ & $\begin{array}{r}3.0412 \\
21.9636 \\
61.6715\end{array}$ \\
\hline \multirow[t]{2}{*}{$90^{\circ}$} & 0.8 & $\begin{array}{l}1 \\
2 \\
3\end{array}$ & $\begin{array}{r}2.1029 \\
21.8524 \\
61.6324\end{array}$ & $\begin{array}{r}2.1096 \\
21.8542 \\
6: .6331\end{array}$ & $\begin{array}{r}2.1029 \\
21.8524 \\
61.6324\end{array}$ & $\begin{array}{r}2.1096 \\
21.8542 \\
51.6331\end{array}$ & $\begin{array}{r}2.1029 \\
21.8524 \\
61.6324\end{array}$ & $\begin{array}{r}2.1029 \\
21.8524 \\
61.6324\end{array}$ & $\begin{array}{r}2.1029 \\
21.8524 \\
61.6324\end{array}$ & $\begin{array}{r}2.1029 \\
21.8524 \\
61.6321\end{array}$ \\
\hline & 1.0 & $\begin{array}{l}1 \\
2 \\
3\end{array}$ & unstable & $\begin{array}{l}\text { Unstable } \\
-\end{array}$ & unstable & Unstable & unstable & unstable & unstable & unstable \\
\hline
\end{tabular}

awonlinear terms due to foreshortening are iqnored.

'Nonlinear terms arising from (TV')' and (I ' ')' are ignored.

CNonlinear terms associatzd with extentional deformation ore ignored.

TABLE VI. - EFFECT OF LINEAR AND NONLINEAR CORIOLIS FORCES, AND VARIGUS NONLINEAR COUPLING IERMS ON THE FREQUENCY PARANE TER RATIOS FOR PRETHISTEO THIN BLADES

(b) $d / b=0.05, C=0^{\circ}, Y=30^{\circ}, R=0$

\begin{tabular}{|c|c|c|c|c|c|c|c|c|c|c|}
\hline \multirow[t]{2}{*}{$B P C$} & \multirow{2}{*}{$\frac{a}{1}$} & \multirow[t]{2}{*}{ Mode } & \multicolumn{2}{|c|}{ Solution of linear equations } & \multicolumn{6}{|c|}{ Perturbation solution of nonlinear equations } \\
\hline & & & $\begin{array}{l}\text { Coriolis } \\
\text { forces } \\
\text { included }\end{array}$ & $\begin{array}{l}\text { Coriolis } \\
\text { forces } \\
\text { ignored }\end{array}$ & $\begin{array}{c}\text { Full } \\
\text { noni inear } \\
\text { equation }\end{array}$ & $\begin{array}{l}\text { Linear } \\
\text { Coriolis } \\
\text { forces } \\
\text { ignored }\end{array}$ & $\begin{array}{c}\text { Nonlinear } \\
\text { Cortol is } \\
\text { forces } \\
\text { ignored }\end{array}$ & $A_{1 j k}=0$ & $D_{i j k}=0$ & $\begin{array}{l}D_{i j k}=0 \\
E_{i j k}=0 \\
p_{i j k}=0 \\
Q_{i j k}=0\end{array}$ \\
\hline \multirow{4}{*}{$15^{\circ}$} & 0.5 & $\begin{array}{l}1 \\
2 \\
3\end{array}$ & $\begin{array}{r}3.9540 \\
20.0667 \\
59.0449\end{array}$ & $\begin{array}{r}3.9551 \\
20.0621 \\
59.0442\end{array}$ & $\begin{array}{r}3.9716 \\
? 0.0716 \\
59.0499\end{array}$ & $\begin{array}{r}3.9772 \\
20.0688 \\
59.0497\end{array}$ & $\begin{array}{r}3.9711 \\
20.0733 \\
59.0504\end{array}$ & $\begin{array}{r}3.9657 \\
20.0715 \\
59.0499\end{array}$ & $\begin{array}{r}3.9600 \\
20.0664 \\
59.0449\end{array}$ & $\begin{array}{r}3.0599 \\
20.0664 \\
59.0450\end{array}$ \\
\hline & 0.8 & $\begin{array}{l}1 \\
2 \\
3\end{array}$ & $\begin{array}{r}4.5355 \\
20.6248 \\
59.6203\end{array}$ & $\begin{array}{r}4.5388 \\
20.6132 \\
59.6184\end{array}$ & $\begin{array}{r}4.6099 \\
20.6488 \\
59.6442\end{array}$ & $\begin{array}{r}4.6107 \\
20.6460 \\
59.6447\end{array}$ & $\begin{array}{r}4.6079 \\
20.6563 \\
59.6470\end{array}$ & $\begin{array}{r}4.5855 \\
20.6477 \\
59.6441\end{array}$ & $\begin{array}{r}4.5613 \\
20.6232 \\
59.6199\end{array}$ & $\begin{array}{r}4.5613 \\
20.6232 \\
59.6202\end{array}$ \\
\hline & 1.0 & $\begin{array}{l}1 \\
? \\
3\end{array}$ & $\begin{array}{r}5.0092 \\
21.1262 \\
60.1438\end{array}$ & $\begin{array}{r}5.0147 \\
21.1087 \\
60.1408\end{array}$ & $\begin{array}{r}5.1416 \\
21.1731 \\
60.1903\end{array}$ & $\begin{array}{r}5.1417 \\
21.1724 \\
60.1922\end{array}$ & $\begin{array}{r}5.1374 \\
? 1.1869 \\
60.1962\end{array}$ & $\begin{array}{r}5.0986 \\
21.1700 \\
60.1904\end{array}$ & $\begin{array}{r}5.0557 \\
21.1225 \\
60.1428\end{array}$ & $\begin{array}{r}5.0557 \\
21.1225 \\
60.1434\end{array}$ \\
\hline & 0.5 & $\begin{array}{l}1 \\
2 \\
3\end{array}$ & $\begin{array}{c}3.500^{\circ} \\
19.8932 \\
58.86 \mathrm{r} 1\end{array}$ & $\begin{array}{r}3.567 ? \\
1900 ? 9 \\
24.0594\end{array}$ & $\begin{array}{r}3.6519 \\
19.9169 \\
58.8890\end{array}$ & $\begin{array}{r}3.6578 \\
19.8912 \\
58.8857\end{array}$ & $\begin{array}{r}3.6499 \\
19.9252 \\
58.8915\end{array}$ & $\begin{array}{r}3.6216 \\
19.9171 \\
58.8889\end{array}$ & $\begin{array}{r}3.5913 \\
19.8922 \\
58.8647\end{array}$ & $\begin{array}{r}3.5913 \\
19.8922 \\
58.8653\end{array}$ \\
\hline \multirow[t]{2}{*}{$45^{\circ}$} & 0.8 & $\begin{array}{l}1 \\
2 \\
3\end{array}$ & $\begin{array}{r}3.5066 \\
20.1907 \\
59.1652\end{array}$ & $\begin{array}{r}3.6265 \\
20.1035 \\
59.1505\end{array}$ & $\begin{array}{r}4.0952 \\
20.3266 \\
59.2997\end{array}$ & $\begin{array}{r}4.1046 \\
20.2884 \\
59.2983\end{array}$ & $\begin{array}{r}4.0841 \\
20.3700 \\
59.3148\end{array}$ & $\begin{array}{r}3.9503 \\
20.3268 \\
59.3035\end{array}$ & $\begin{array}{r}3.7928 \\
20.1820 \\
59.1620\end{array}$ & $\begin{array}{r}3.7928 \\
20.1821 \\
59.1654\end{array}$ \\
\hline & 1.0 & $\begin{array}{l}1 \\
2 \\
3 \\
\end{array}$ & $\begin{array}{r}3.6481 \\
20.4614 \\
59.4402 \\
\end{array}$ & $\begin{array}{r}3.6791 \\
20.3265 \\
59.4172 \\
\end{array}$ & $\begin{array}{r}4.6005 \\
20.7467 \\
59.7200 \\
\end{array}$ & $\begin{array}{r}4.6089 \\
20.7138 \\
59.7250 \\
\end{array}$ & $\begin{array}{r}4.5765 \\
20.8328 \\
59.7531 \\
\end{array}$ & $\begin{array}{r}4.3454 \\
20.7483 \\
59.7361 \\
\end{array}$ & $\begin{array}{r}4.0477 \\
20.4387 \\
59.4320 \\
\end{array}$ & $\begin{array}{r}4.0477 \\
20.4388 \\
59.4388\end{array}$ \\
\hline
\end{tabular}


TABLE VII. - EFFECT OF LINEAR ANO MONLINEAR CORIOLIS FORCES, ANO VARIOUS MONLINEAR COUPLIMC TERMS OM THE TRCQUCHCY FARAMHCTER RATIOS FOR THICK DLAOESS

(a) $d / b=0.25,=0^{\circ}, Y=0^{\circ}, \bar{R}=0$

\begin{tabular}{|c|c|c|c|c|c|c|c|c|c|c|}
\hline \multirow[t]{2}{*}{ Ppc } & \multirow{2}{*}{$\frac{0}{41}$} & \multirow[t]{2}{*}{ Mode } & \multicolumn{2}{|c|}{ Solution of linear equations } & \multicolumn{6}{|c|}{ Perturbation solution of nonlinear equations } \\
\hline & & & $\begin{array}{l}\text { Coriolis } \\
\text { forces } \\
\text { includec }\end{array}$ & $\begin{array}{l}\text { Coriolis } \\
\text { forces } \\
\text { ignored }\end{array}$ & $\begin{array}{c}\text { Full } \\
\text { nonlinear } \\
\text { equation }\end{array}$ & $\begin{array}{l}\text { Linear } \\
\text { Coriolis } \\
\text { forces } \\
\text { ignored }\end{array}$ & $\begin{array}{c}\text { Nonlinear } \\
\text { Coriolis } \\
\text { forces } \\
\text { ignored }\end{array}$ & $A_{i j k}=0$ & $\begin{array}{l}n_{f j k}=0 \\
E_{j j k}=0\end{array}$ & $\begin{array}{l}D_{i j k}=0 \\
E_{i j k}=0 \\
P_{i j k}=0 \\
Q_{i j k}=0\end{array}$ \\
\hline \multirow{4}{*}{$15^{\circ}$} & 0.5 & $\begin{array}{l}1 \\
2 \\
3\end{array}$ & $\begin{array}{r}3.9390 \\
14.1019 \\
22.4485\end{array}$ & $\begin{array}{r}3.9480 \\
14.0765 \\
22.4498\end{array}$ & $\begin{array}{r}3.9600 \\
14.0905 \\
22.4568\end{array}$ & $\begin{array}{r}3.9650 \\
14.0793 \\
22.4575\end{array}$ & $\begin{array}{r}3.9565 \\
14.1034 \\
22.4556\end{array}$ & $\begin{array}{r}3.9527 \\
14.0964 \\
22.4550\end{array}$ & $\begin{array}{r}3.9469 \\
14.0947 \\
22.4494\end{array}$ & $\begin{array}{r}3.9468 \\
14.0948 \\
22.4497\end{array}$ \\
\hline & 0.8 & $\begin{array}{l}1 \\
2 \\
3\end{array}$ & $\begin{array}{r}4.5097 \\
14.1628 \\
23.0795\end{array}$ & $\begin{array}{r}4.5365 \\
14.0958 \\
23.0829\end{array}$ & $\begin{array}{r}4.6011 \\
14.1117 \\
23.1215\end{array}$ & $\begin{array}{r}4.6055 \\
14.1154 \\
23.1223\end{array}$ & $\begin{array}{r}4.5831 \\
14.1702 \\
23.1142\end{array}$ & $\begin{array}{r}4.5707 \\
14.1351 \\
23.1111\end{array}$ & $\begin{array}{r}4.5464 \\
14.1268 \\
23.0842\end{array}$ & $\begin{array}{r}4.5458 \\
14.1270 \\
23.0852\end{array}$ \\
\hline & 1.0 & $\begin{array}{l}1 \\
2 \\
3\end{array}$ & $\begin{array}{r}4.9684 \\
14.2210 \\
23.6470\end{array}$ & $\begin{array}{r}5.0154 \\
14.1134 \\
23.6524\end{array}$ & $\begin{array}{r}5.1351 \\
14.1258 \\
23.7297\end{array}$ & $\begin{array}{r}5.1324 \\
14.1598 \\
23.7302\end{array}$ & $\begin{array}{r}5.0977 \\
14.2358 \\
23.7146\end{array}$ & $\begin{array}{r}5.0816 \\
14.1654 \\
23.7090\end{array}$ & $\begin{array}{r}5.0388 \\
14.1486 \\
23.6570\end{array}$ & $\begin{array}{r}5.0376 \\
14.1488 \\
23.6579\end{array}$ \\
\hline & 0.5 & $\begin{array}{l}1 \\
2 \\
3\end{array}$ & $\begin{array}{r}3.4993 \\
14.2495 \\
22.2162\end{array}$ & $\begin{array}{r}3.5575 \\
14.0196 \\
22.27 .56\end{array}$ & $\begin{array}{r}3.6057 \\
14.1940 \\
22.2544\end{array}$ & $\begin{array}{r}3.6486 \\
14.0310 \\
22.2614\end{array}$ & $\begin{array}{r}3.5900 \\
14.2570 \\
22.2499\end{array}$ & $\begin{array}{r}3.5690 \\
14.2234 \\
22.2469\end{array}$ & $\begin{array}{r}3.5387 \\
14.2150 \\
22.2194\end{array}$ & $\begin{array}{r}3.5387 \\
14.2155 \\
22.2220\end{array}$ \\
\hline \multirow[t]{2}{*}{$45^{\circ}$} & 0.8 & $\begin{array}{l}1 \\
2 \\
3\end{array}$ & $\begin{array}{r}3.4722 \\
14.5337 \\
22.4961\end{array}$ & $\begin{array}{r}3.6198 \\
13.9500 \\
22.5206\end{array}$ & $\begin{array}{r}4.0238 \\
14.2520 \\
22.7230\end{array}$ & $\begin{array}{r}4.0880 \\
14.0405 \\
22.7332\end{array}$ & $\begin{array}{r}3.9369 \\
14.5808 \\
22.6865\end{array}$ & $\begin{array}{r}3.85: 2 \\
14.3878 \\
22.6747\end{array}$ & $\begin{array}{r}3.6990 \\
14.3300 \\
22.5167\end{array}$ & $\begin{array}{r}3.6489 \\
14.3331 \\
22.5308\end{array}$ \\
\hline & 1.0 & $\begin{array}{l}1 \\
2 \\
3\end{array}$ & $\begin{array}{r}3.4464 \\
14.7907 \\
22.7509\end{array}$ & $\begin{array}{r}3.6747 \\
13.8854 \\
22.7895\end{array}$ & $\begin{array}{r}4.5133 \\
14.2478 \\
23.2316\end{array}$ & $\begin{array}{r}4.5621 \\
14.1138 \\
23.2414\end{array}$ & $\begin{array}{r}4.3263 \\
14.8973 \\
23.1473\end{array}$ & $\begin{array}{r}4.2119 \\
14.4868 \\
23.1333\end{array}$ & $\begin{array}{r}3.9309 \\
14.3435 \\
22.7998\end{array}$ & $\begin{array}{r}3.9308 \\
14.3499 \\
22.8273\end{array}$ \\
\hline
\end{tabular}

TABLE VII. - EFFECT OF LINEAR AND NONLINEAR CORIOLIS FORCES, AND VARIOUS NONL INEAR COUPLING TERMS ON THE FREQUENCY PARAMETER RATIOS FOR PRETHISTEO THICK BLADES

(b) $d / 0=0.25, \sigma=0^{\circ}, \bar{R}=0 \mathrm{r},=30^{\circ}$

\begin{tabular}{|c|c|c|c|c|c|c|c|c|c|c|}
\hline \multirow[t]{2}{*}{ BPc } & \multirow{2}{*}{$\frac{a}{\infty 1}$} & \multirow[t]{2}{*}{ Mode } & \multicolumn{2}{|c|}{ Solution of linear equations } & \multicolumn{6}{|c|}{ Perturbation solution of nonlinear equations } \\
\hline & & & $\begin{array}{l}\text { Coriolis } \\
\text { forces } \\
\text { included }\end{array}$ & $\begin{array}{l}\text { Corivi is } \\
\text { forces } \\
\text { ignored }\end{array}$ & $\begin{array}{c}\text { Full } \\
\text { nonlinear } \\
\text { equation }\end{array}$ & $\begin{array}{l}\text { Linear } \\
\text { Coriolis } \\
\text { forces } \\
\text { ignored }\end{array}$ & $\begin{array}{c}\text { Nonlinear } \\
\text { Coriolis } \\
\text { forces } \\
\text { ignored }\end{array}$ & $A_{i j k}=0$ & $\begin{array}{l}D_{i j k}=0 \\
E_{i j k}=0\end{array}$ & $\begin{array}{l}D_{i j k}=0 \\
E_{i j k}=0 \\
P_{i j k}=0 \\
Q_{i j k}=0\end{array}$ \\
\hline \multirow{4}{*}{$15^{\circ}$} & 0.5 & $\begin{array}{l}1 \\
2 \\
3\end{array}$ & $\begin{array}{r}3.9439 \\
13.2169 \\
24.0327\end{array}$ & $\begin{array}{r}3.9538 \\
13.1901 \\
24.0341\end{array}$ & $\begin{array}{r}3.9649 \\
13.2064 \\
24.0394\end{array}$ & $\begin{array}{r}3.9705 \\
13.1937 \\
24.0408\end{array}$ & $\begin{array}{r}3.9611 \\
13.2191 \\
24.0388\end{array}$ & $\begin{array}{r}3.9576 \\
13.2120 \\
24.0381\end{array}$ & $\begin{array}{r}3.9518 \\
13.2098 \\
24.0331\end{array}$ & $\begin{array}{r}3.9517 \\
13.2099 \\
24.0335\end{array}$ \\
\hline & 0.8 & $\begin{array}{l}1 \\
2 \\
3\end{array}$ & $\begin{array}{r}4.5074 \\
13.3419 \\
24.5895\end{array}$ & $\begin{array}{r}4.5369 \\
13.2712 \\
24.5933\end{array}$ & $\begin{array}{r}4.5995 \\
13.2948 \\
24.6244\end{array}$ & $\begin{array}{r}4.6048 \\
13.2944 \\
24.6279\end{array}$ & $\begin{array}{r}4.5800 \\
13.3524 \\
24.6198\end{array}$ & $\begin{array}{r}4.5687 \\
13.3169 \\
24.6164\end{array}$ & $\begin{array}{r}4.5446 \\
13.3061 \\
24.5923\end{array}$ & $\begin{array}{r}4.5441 \\
13.3062 \\
24.5936\end{array}$ \\
\hline & 1.0 & $\begin{array}{l}1 \\
2 \\
3\end{array}$ & $\begin{array}{r}4.9606 \\
13.4530 \\
25.0954\end{array}$ & $\begin{array}{r}5.0122 \\
13.3393 \\
25.1018\end{array}$ & $\begin{array}{r}5.1294 \\
13.3642 \\
25.1650\end{array}$ & $\begin{array}{r}5.1273 \\
13.3926 \\
25.1711\end{array}$ & $\begin{array}{r}5.08888 \\
13.4734 \\
251554\end{array}$ & $\begin{array}{r}5.0750 \\
13.4016 \\
25.1492\end{array}$ & $\begin{array}{r}5.0325 \\
13.3805 \\
25.1022\end{array}$ & $\begin{array}{r}5.0313 \\
13.3804 \\
25.1037\end{array}$ \\
\hline & 0.5 & $\begin{array}{l}1 \\
2 \\
3\end{array}$ & $\begin{array}{r}3.5016 \\
13.3418 \\
23.8329\end{array}$ & $\begin{array}{r}3.5658 \\
13.1097 \\
23.8359\end{array}$ & $\begin{array}{r}3.6075 \\
13.2916 \\
23.8630\end{array}$ & $\begin{array}{r}3.6553 \\
13.1247 \\
23.8664\end{array}$ & $\begin{array}{r}3.5907 \\
13.3530 \\
23.8616\end{array}$ & $\begin{array}{r}3.5708 \\
13.3197 \\
23.8578\end{array}$ & $\begin{array}{r}3.5410 \\
13.3084 \\
23.8337\end{array}$ & $\begin{array}{r}3.5410 \\
13.3089 \\
23.8367\end{array}$ \\
\hline \multirow[t]{2}{*}{$15^{\circ}$} & 0.8 & $\begin{array}{l}1 \\
2 \\
3\end{array}$ & $\begin{array}{r}3.4631 \\
13.6592 \\
24.0827\end{array}$ & $\begin{array}{r}3.6246 \\
13.0703 \\
24.0918\end{array}$ & $\begin{array}{r}4.0136 \\
13.4067 \\
24.2659\end{array}$ & $\begin{array}{r}4.0863 \\
13.1819 \\
24.2760\end{array}$ & $\begin{array}{r}3.9205 \\
13.7269 \\
24.2461\end{array}$ & $\begin{array}{r}3.8410 \\
13.5344 \\
24.2301\end{array}$ & $\begin{array}{r}3.6897 \\
13.4611 \\
24.0899\end{array}$ & $\begin{array}{r}3.6896 \\
13.4639 \\
24.1052\end{array}$ \\
\hline & 1.0 & $\begin{array}{l}1 \\
2 \\
3 \\
\end{array}$ & $\begin{array}{r}3.4281 \\
13.9447 \\
24.3105 \\
\end{array}$ & $\begin{array}{r}3.6766 \\
13.0318 \\
24.3268 \\
\end{array}$ & $\begin{array}{r}4.4952 \\
13.4582 \\
24.7071 \\
\end{array}$ & $\begin{array}{r}4.5530 \\
13.3039 \\
24.7230 \\
\end{array}$ & $\begin{array}{r}4.2956 \\
14.0933 \\
24.6541 \\
\end{array}$ & $\begin{array}{r}4.1909 \\
13.6823 \\
24.6313\end{array}$ & $\begin{array}{r}3.9127 \\
13.5075 \\
24.3319 \\
\end{array}$ & $\begin{array}{r}3.9125 \\
13.5130 \\
24.3640 \\
\end{array}$ \\
\hline
\end{tabular}




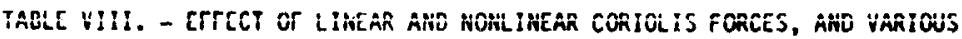
MONLINEAR TERMS ON THE FREQUEMCY PARAMETER RATIOS

[Presented as percent frequency variation based upon full nonlinear equation solution. ( $\left.\left.f_{\text {nonlinear }}-f_{\text {reference }}\right) \times 100 / f_{\text {nonlinear. }}\right]$

(3) $B P_{C}=15^{\circ},=r=0^{\circ}, R=0$

\begin{tabular}{|c|c|c|c|c|c|c|}
\hline$\frac{a}{1}$ & Mode & $\begin{array}{l}\text { All nonlinear } \\
\text { terms Ignored }\end{array}$ & $\begin{array}{l}\text { Linear Coriolis } \\
\text { forces Ignored }\end{array}$ & $\begin{array}{l}\text { Monlinear Coriolis } \\
\text { forces ignored }\end{array}$ & $A_{1 j k}=0$ & $\begin{array}{l}D_{i j k}=0 \\
E_{i j k}=0\end{array}$ \\
\hline \multicolumn{7}{|c|}{ Thin blade: $(\mathrm{d} / \mathrm{b})=0.05$} \\
\hline $\begin{array}{l}0.5 \\
0.8 \\
1.0\end{array}$ & $\begin{array}{l}1 \\
1 \\
1\end{array}$ & $\begin{array}{l}0.4439 \\
1.6011 \\
2.5387\end{array}$ & $\begin{array}{r}-0.0050 \\
-0.0043 \\
0.0019\end{array}$ & $\begin{array}{l}0.0050 \\
0.0152 \\
0.0253\end{array}$ & $\begin{array}{l}0.1488 \\
0.5250 \\
0.8223\end{array}$ & $\begin{array}{l}0.2951 \\
1.0544 \\
1.6620\end{array}$ \\
\hline $\begin{array}{l}0.5 \\
0.8 \\
1.0\end{array}$ & $\begin{array}{l}2 \\
2 \\
2\end{array}$ & $\begin{array}{l}0.0330 \\
0.1531 \\
0.2871\end{array}$ & $\begin{array}{l}0.0 \\
0.0 \\
0.0004\end{array}$ & $\begin{array}{l}0.0 \\
-0.0013 \\
-0.0030\end{array}$ & $\begin{array}{l}0.0040 \\
0.0173 \\
0.0304\end{array}$ & $\begin{array}{l}0.0289 \\
0.1337 \\
0.2496\end{array}$ \\
\hline $\begin{array}{l}0.5 \\
0.8 \\
1.0\end{array}$ & $\begin{array}{l}3 \\
3 \\
3\end{array}$ & $\begin{array}{l}0.0090 \\
0 . v 397 \\
0.0727\end{array}$ & $\begin{array}{l}0.0 \\
0.0 \\
0.0002\end{array}$ & $\begin{array}{l}-0.0036 \\
-0.0070 \\
-0.0181\end{array}$ & $\begin{array}{l}-0.0001 \\
-0.0046 \\
-0.0139\end{array}$ & $\begin{array}{l}0.0087 \\
0.0379 \\
0.069 i\end{array}$ \\
\hline \multicolumn{7}{|c|}{ Irick blade: $\left(A^{\prime} ; 0\right)=0.25$} \\
\hline $\begin{array}{l}0.5 \\
0.8 \\
1.0\end{array}$ & $\begin{array}{l}1 \\
1 \\
1\end{array}$ & $\begin{array}{l}0.5303 \\
1.9865 \\
3.2463\end{array}$ & $\begin{array}{r}-0.1263 \\
-0.0956 \\
0.0526\end{array}$ & $\begin{array}{l}0.0884 \\
0.3512 \\
0.7283\end{array}$ & $\begin{array}{l}0.1843 \\
0.6607 \\
1.0419\end{array}$ & $\begin{array}{l}0.3308 \\
1.1889 \\
1.7753\end{array}$ \\
\hline $\begin{array}{l}0.5 \\
0.8 \\
1.0\end{array}$ & $\begin{array}{l}2 \\
2 \\
2\end{array}$ & $\begin{array}{l}-0.0809 \\
-0.3621 \\
-0.6739\end{array}$ & $\begin{array}{r}0.0795 \\
-0.0262 \\
-0.2407\end{array}$ & $\begin{array}{l}-0.0916 \\
-0.4146 \\
-0.7787\end{array}$ & $\begin{array}{l}-0.0419 \\
-0.1658 \\
-0.2803\end{array}$ & $\begin{array}{l}-0.0298 \\
-0.1070 \\
-0.1614\end{array}$ \\
\hline $\begin{array}{l}0.5 \\
0.8 \\
1.0\end{array}$ & $\begin{array}{l}3 \\
3 \\
3\end{array}$ & $\begin{array}{l}0.0370 \\
0.1817 \\
0.3485\end{array}$ & $\begin{array}{l}-0.0031 \\
-0.0035 \\
-0.0021\end{array}$ & $\begin{array}{l}0.0053 \\
0.0316 \\
0.0636\end{array}$ & $\begin{array}{l}0.0080 \\
0.0450 \\
0.0872\end{array}$ & $\begin{array}{l}0.0330 \\
0.1613 \\
0.3064\end{array}$ \\
\hline
\end{tabular}

(b) $\left.{ }_{B P C}=45^{\circ}, \ldots=0^{\circ}, R=0.\right\}$

\begin{tabular}{|c|c|c|c|c|c|c|}
\hline$\frac{a}{11}$ & Mode & $\begin{array}{l}\text { All nonlinear } \\
\text { terms ignored }\end{array}$ & $\begin{array}{l}\text { Linear Coriolis } \\
\text { forces ignored }\end{array}$ & $\begin{array}{l}\text { Nonl inear Coriolis } \\
\text { forces ignored }\end{array}$ & $A_{i j k}=0$ & $\begin{array}{l}0_{i j k}=0 \\
E_{i j k}=0\end{array}$ \\
\hline \multicolumn{7}{|c|}{ Thin blade: $\quad(d / b)=0.05$} \\
\hline $\begin{array}{l}0.5 \\
0.8 \\
1.0\end{array}$ & $\begin{array}{l}1 \\
1 \\
1\end{array}$ & $\begin{array}{r}2.5465 \\
11.9071 \\
20.5569\end{array}$ & $\begin{array}{l}-0.0439 \\
-0.0550 \\
-0.0412\end{array}$ & $\begin{array}{l}0.0165 \\
0.0853 \\
0.1647\end{array}$ & $\begin{array}{l}0.8278 \\
3.4978 \\
5.4630\end{array}$ & $\begin{array}{r}1.9188 \\
7.3904 \\
11.9710\end{array}$ \\
\hline $\begin{array}{l}0.5 \\
0.8 \\
1.0\end{array}$ & $\begin{array}{l}2 \\
2 \\
2\end{array}$ & $\begin{array}{l}0.1635 \\
0.8899 \\
1.7958\end{array}$ & $\begin{array}{r}-0.0009 \\
-0.0001 \\
0.0009\end{array}$ & $\begin{array}{l}0.0 \\
-0.0053 \\
-0.0142\end{array}$ & $\begin{array}{l}0.0189 \\
0.0739 \\
0.0996\end{array}$ & $\begin{array}{l}0.1424 \\
0.7567 \\
1.5286\end{array}$ \\
\hline $\begin{array}{l}0.5 \\
0.8 \\
1.0\end{array}$ & $\begin{array}{l}3 \\
3 \\
3\end{array}$ & $\begin{array}{l}0.0442 \\
0.2334 \\
0.4626\end{array}$ & $\begin{array}{c}-0.0002 \\
0.0 \\
0.0006\end{array}$ & $\begin{array}{l}-0.0021 \\
-0.0282 \\
-0.0813\end{array}$ & $\begin{array}{r}0.0002 \\
-0.0229 \\
-0.0850\end{array}$ & $\begin{array}{l}0.0433 \\
0.2264 \\
0.4455\end{array}$ \\
\hline \multicolumn{7}{|c|}{ Thick blade: $(d / b)=0.25$} \\
\hline $\begin{array}{l}0.5 \\
0.8 \\
1.0\end{array}$ & $\begin{array}{l}1 \\
1 \\
1\end{array}$ & $\begin{array}{r}2.9509 \\
13.7084 \\
23.6390\end{array}$ & $\begin{array}{l}-1.1898 \\
-1.5955 \\
-1.0813\end{array}$ & $\begin{array}{l}0.4354 \\
2.1597 \\
4.1433\end{array}$ & $\begin{array}{l}1.1078 \\
4.2646 \\
6.6780\end{array}$ & $\begin{array}{r}1.8582 \\
8.0720 \\
12.9041\end{array}$ \\
\hline $\begin{array}{l}0.5 \\
0.8 \\
1.0\end{array}$ & $\begin{array}{l}2 \\
2 \\
2\end{array}$ & $\begin{array}{l}-0.3910 \\
-1.9766 \\
-3.9104\end{array}$ & $\begin{array}{l}1.1484 \\
1.4840 \\
0.9405\end{array}$ & $\begin{array}{l}-0.4439 \\
-2.3071 \\
-4.5586\end{array}$ & $\begin{array}{l}-0.2071 \\
-0.9529 \\
-1.6775\end{array}$ & $\begin{array}{l}-0.1480 \\
-0.547 \\
-0.6717\end{array}$ \\
\hline $\begin{array}{l}0.5 \\
0.8 \\
1.0\end{array}$ & $\begin{array}{l}3 \\
3 \\
3\end{array}$ & $\begin{array}{l}0.171 ? \\
0.9986 \\
2.0692\end{array}$ & $\begin{array}{r}-0.0315 \\
-0.0449 \\
0.0422\end{array}$ & $\begin{array}{l}0.0202 \\
0.1606 \\
0.3629\end{array}$ & $\begin{array}{l}0.03337 \\
0.2126 \\
0.4231 \\
\end{array}$ & $\begin{array}{l}0.1573 \\
0.9079 \\
1.8587 \\
\end{array}$ \\
\hline
\end{tabular}


TABLE IX. - EFFECT OF LIMEAR AND NONLIMEAR CORIOLIS FORCES, AND VARIOUS HONLIMEAR TERMS ON THE TKEQUENCY PAKAHETER RATIOS

[Presented as percent frequency variation based upon full nonlinear equation solution.])

$$
\text { (a) } x_{p c}=15^{\circ}, .=0^{\circ}, R=0, Y=30^{\circ}
$$

\begin{tabular}{|c|c|c|c|c|c|c|}
\hline$\frac{a}{1}$ & Mode & $\begin{array}{l}\text { Ali nonlinear } \\
\text { terms iglored }\end{array}$ & $\begin{array}{l}\text { Lnear Corfolls } \\
\text { forces ignored }\end{array}$ & $\begin{array}{l}\text { Nonlinear Coriolis } \\
\text { forces Ignored }\end{array}$ & $A_{f j k}=0$ & $\begin{array}{l}D_{i j k}=0 \\
E_{i j k}=0\end{array}$ \\
\hline \multicolumn{7}{|c|}{ Thin blade: $(d / b)=0.05$} \\
\hline $\begin{array}{l}0.5 \\
0.8 \\
1.0\end{array}$ & $\begin{array}{l}1 \\
1 \\
1\end{array}$ & $\begin{array}{l}0.4432 \\
1.6139 \\
2.5751\end{array}$ & $\begin{array}{l}-0.0151 \\
-0.0174 \\
-0.0019\end{array}$ & $\begin{array}{l}0.0126 \\
0.0434 \\
0.0817\end{array}$ & $\begin{array}{l}0.1486 \\
0.5293 \\
0.8363\end{array}$ & $\begin{array}{l}0.2921 \\
1.0543 \\
1.6709\end{array}$ \\
\hline $\begin{array}{l}0.5 \\
0.8 \\
1.0\end{array}$ & $\begin{array}{l}2 \\
2 \\
2\end{array}$ & $\begin{array}{l}0.0244 \\
0.1162 \\
0.2215\end{array}$ & $\begin{array}{l}0.0140 \\
0.0136 \\
0.0033\end{array}$ & $\begin{array}{l}-0.0085 \\
-0.0363 \\
-0.0652\end{array}$ & $\begin{array}{l}0.0005 \\
0.0053 \\
0.0146\end{array}$ & $\begin{array}{l}0.0259 \\
0.1240 \\
0.2390\end{array}$ \\
\hline $\begin{array}{l}0.5 \\
0.8 \\
1.0 \\
\end{array}$ & $\begin{array}{l}3 \\
3 \\
3\end{array}$ & $\begin{array}{l}0.0085 \\
0.0401 \\
0.0773\end{array}$ & $\begin{array}{r}0.0003 \\
-0.0008 \\
-0.0032 \\
\end{array}$ & $\begin{array}{l}-0.0009 \\
-0.0047 \\
-0.0098\end{array}$ & $\begin{array}{l}0.0 \\
0.0002 \\
-0.0002\end{array}$ & $\begin{array}{l}0.0005 \\
0.0407 \\
0.0789\end{array}$ \\
\hline \multicolumn{7}{|c|}{ Thick blade: $(d / b)=0.25$} \\
\hline $\begin{array}{l}0.5 \\
0.8 \\
1.0\end{array}$ & $\begin{array}{l}1 \\
1 \\
1\end{array}$ & $\begin{array}{l}0.5297 \\
2.0024 \\
3.2908\end{array}$ & $\begin{array}{r}-0.1412 \\
-0.1152 \\
0.0409\end{array}$ & $\begin{array}{l}0.0958 \\
0.4240 \\
0.7915\end{array}$ & $\begin{array}{l}0.1841 \\
0.6696 \\
1.0606\end{array}$ & $\begin{array}{l}0.3304 \\
1.1936 \\
1.8891\end{array}$ \\
\hline $\begin{array}{l}0.5 \\
0.8 \\
1.0\end{array}$ & $\begin{array}{l}2 \\
2 \\
2\end{array}$ & $\begin{array}{l}-0.0795 \\
-0.3543 \\
-0.6645\end{array}$ & $\begin{array}{r}0.0962 \\
0.0030 \\
-0.2125\end{array}$ & $\begin{array}{l}-0.0962 \\
-0.4333 \\
-0.8171\end{array}$ & $\begin{array}{l}-0.0424 \\
-0.1662 \\
-0.2799\end{array}$ & $\begin{array}{l}-0.0258 \\
-0.0850 \\
-0.1220\end{array}$ \\
\hline $\begin{array}{l}0.5 \\
0.8 \\
1.0\end{array}$ & $\begin{array}{l}3 \\
3 \\
3\end{array}$ & $\begin{array}{l}0.0279 \\
0.0417 \\
0.2801 \\
\end{array}$ & $\begin{array}{l}-0.0058 \\
-0.0142 \\
-0.0207 \\
\end{array}$ & $\begin{array}{l}0.0025 \\
0.0187 \\
0.0417 \\
\end{array}$ & $\begin{array}{l}0.0054 \\
0.0325 \\
0.0664 \\
\end{array}$ & $\begin{array}{l}0.0262 \\
0.1304 \\
0.2531 \\
\end{array}$ \\
\hline
\end{tabular}

(b) $B P_{C}=45^{\circ}, Q=0^{\circ}, R=0, Y=30^{\circ}$

\begin{tabular}{|c|c|c|c|c|c|c|}
\hline$\frac{2}{w_{1}}$ & Mode & $\begin{array}{l}\text { All nonlinear } \\
\text { terms ignored }\end{array}$ & $\begin{array}{l}\text { Linear Coriol is } \\
\text { forces ignored }\end{array}$ & $\begin{array}{l}\text { Nonlinear Corio! is } \\
\text { forces ignored }\end{array}$ & $A_{i j k}=0$ & $\begin{array}{l}D_{i j k}=0 \\
E_{i j k}=0\end{array}$ \\
\hline \multicolumn{7}{|c|}{ Thin blade: $(\mathrm{d} / \mathrm{b})=0.05$} \\
\hline $\begin{array}{l}0.5 \\
0.8 \\
1.0\end{array}$ & $\begin{array}{l}1 \\
1 \\
1\end{array}$ & $\begin{array}{r}2.5329 \\
11.9310 \\
20.7021\end{array}$ & $\begin{array}{l}-0.1616 \\
-0.2295 \\
-0.1826\end{array}$ & $\begin{array}{l}0.0548 \\
0.2711 \\
0.5217\end{array}$ & $\begin{array}{l}0.8297 \\
3.5383 \\
5.5451\end{array}$ & $\begin{array}{r}1.6594 \\
7.3843 \\
12.0161\end{array}$ \\
\hline $\begin{array}{l}0.5 \\
0.8 \\
1.0\end{array}$ & $\begin{array}{l}2 \\
2 \\
2\end{array}$ & $\begin{array}{l}0.1190 \\
0.6686 \\
1.3752\end{array}$ & $\begin{array}{l}0.1290 \\
0.1879 \\
0.1586\end{array}$ & $\begin{array}{l}-0.0417 \\
-0.2135 \\
-0.4150\end{array}$ & $\begin{array}{r}-0.00: 0 \\
0.6010 \\
-0,0077\end{array}$ & $\begin{array}{l}0.1240 \\
0.7114 \\
1.4846\end{array}$ \\
\hline $\begin{array}{l}0.5 \\
0.8 \\
1.0\end{array}$ & $\begin{array}{l}3 \\
3 \\
3\end{array}$ & $\begin{array}{l}0.0406 \\
0.2268 \\
0.4685\end{array}$ & $\begin{array}{r}0.0056 \\
0.0024 \\
-0.0084\end{array}$ & $\begin{array}{l}-0.0043 \\
-0.0255 \\
-0.0554\end{array}$ & $\begin{array}{r}0.0002 \\
-0.0064 \\
-0.0270\end{array}$ & $\begin{array}{l}0.0413 \\
0.2322 \\
0.4823\end{array}$ \\
\hline \multicolumn{7}{|c|}{ Thick blade: $(d / b)=0.25$} \\
\hline $\begin{array}{l}0.5 \\
0.8 \\
1.0\end{array}$ & $\begin{array}{l}1 \\
1 \\
1\end{array}$ & $\begin{array}{r}2.9356 \\
13.7159 \\
23.7387\end{array}$ & $\begin{array}{l}-1.3250 \\
-1.8113 \\
-1.2858\end{array}$ & $\begin{array}{l}0.4657 \\
2.3196 \\
4.4403\end{array}$ & $\begin{array}{l}1.0173 \\
4.3004 \\
6.7694\end{array}$ & $\begin{array}{r}1.8434 \\
8.0701 \\
12.9583\end{array}$ \\
\hline $\begin{array}{l}0.5 \\
0.8 \\
1.0\end{array}$ & $\begin{array}{l}2 \\
2 \\
2\end{array}$ & $\begin{array}{l}-0.3777 \\
-1.8834 \\
-3.6149\end{array}$ & $\begin{array}{l}1.2557 \\
1.6768 \\
1.1465\end{array}$ & $\begin{array}{l}-0.4620 \\
-2.3884 \\
-4.7191\end{array}$ & $\begin{array}{r}-0.2114 \\
-0.9525 \\
1.6652\end{array}$ & $\begin{array}{l}-0.1264 \\
-0.4058 \\
-0.3663\end{array}$ \\
\hline $\begin{array}{l}0.5 \\
0.8 \\
1.0 \\
\end{array}$ & $\begin{array}{l}3 \\
3 \\
3 \\
\end{array}$ & $\begin{array}{l}0.1261 \\
0.7550 \\
1.6052 \\
\end{array}$ & $\begin{array}{l}-0.0143 \\
-0.0416 \\
-0.0644 \\
\end{array}$ & $\begin{array}{l}0.0059 \\
0.0816 \\
0.2145 \\
\end{array}$ & $\begin{array}{l}0.0218 \\
0.11775 \\
0.3068 \\
\end{array}$ & $\begin{array}{l}0.1228 \\
0.7253 \\
1.5186 \\
\end{array}$ \\
\hline
\end{tabular}




\section{Culatinal PAGE IS \\ OF. POON QUALITY}

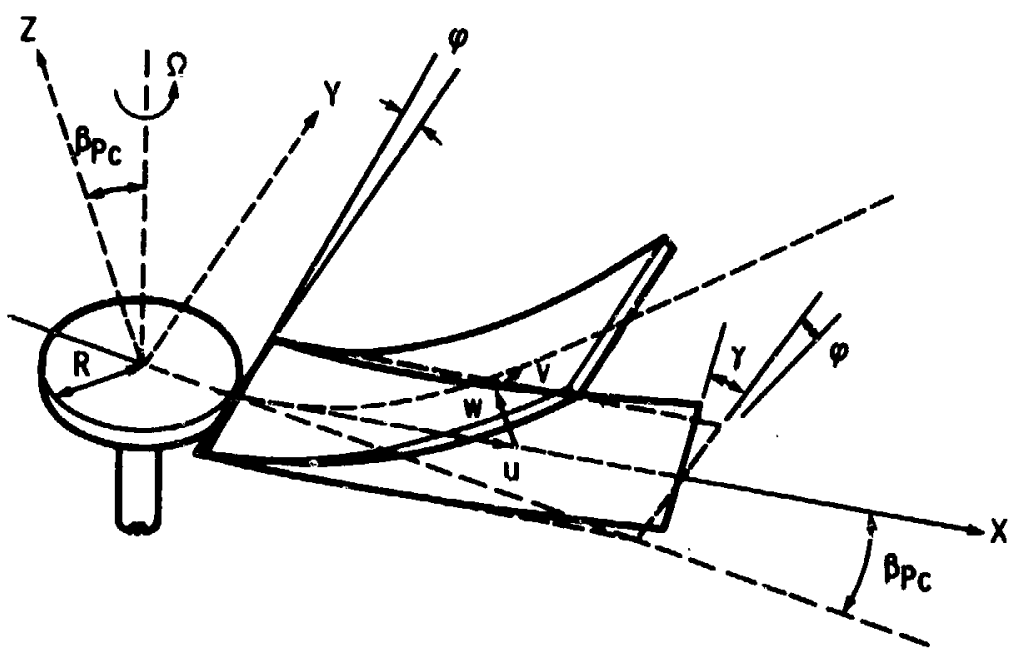

Figure 1. - Blade coordinate system and definition of blade parameters. 


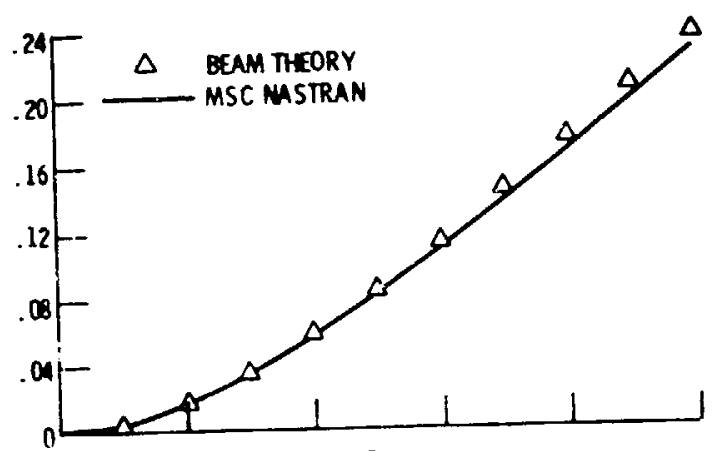

(a) $A_{x c}=30^{\circ}, 8 / y_{y}=0.7$.

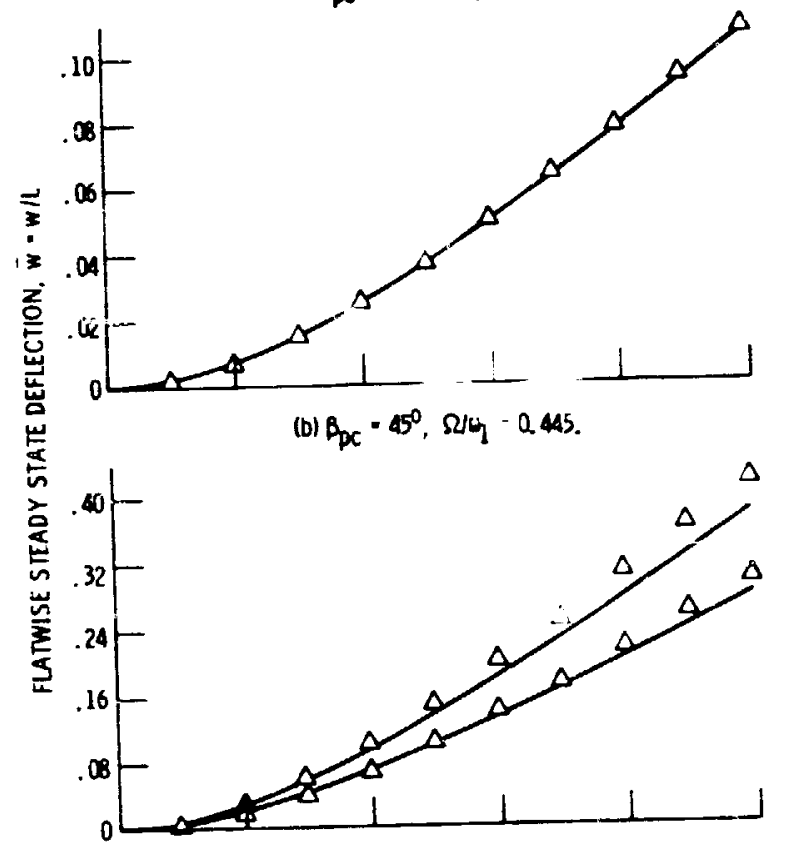

(c) $\mathrm{B}_{\mathrm{xc}}=\mathrm{C}^{\infty}, 8 / 4 \mathrm{y}=0.8$ and 1,05 .

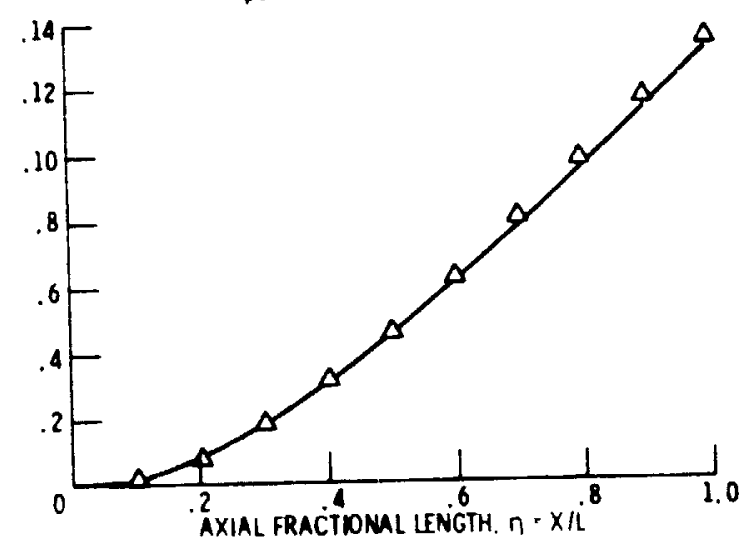

(1) $B_{p c} \cdot 60^{\circ}, \Omega y_{y} \cdot 0.5$.

figure 2. - Comparison of stady state deflection $\bar{w}$, distribution along the length of a thin blade $1010 \cdot 0.051$ for warious precones and robtional speads. 


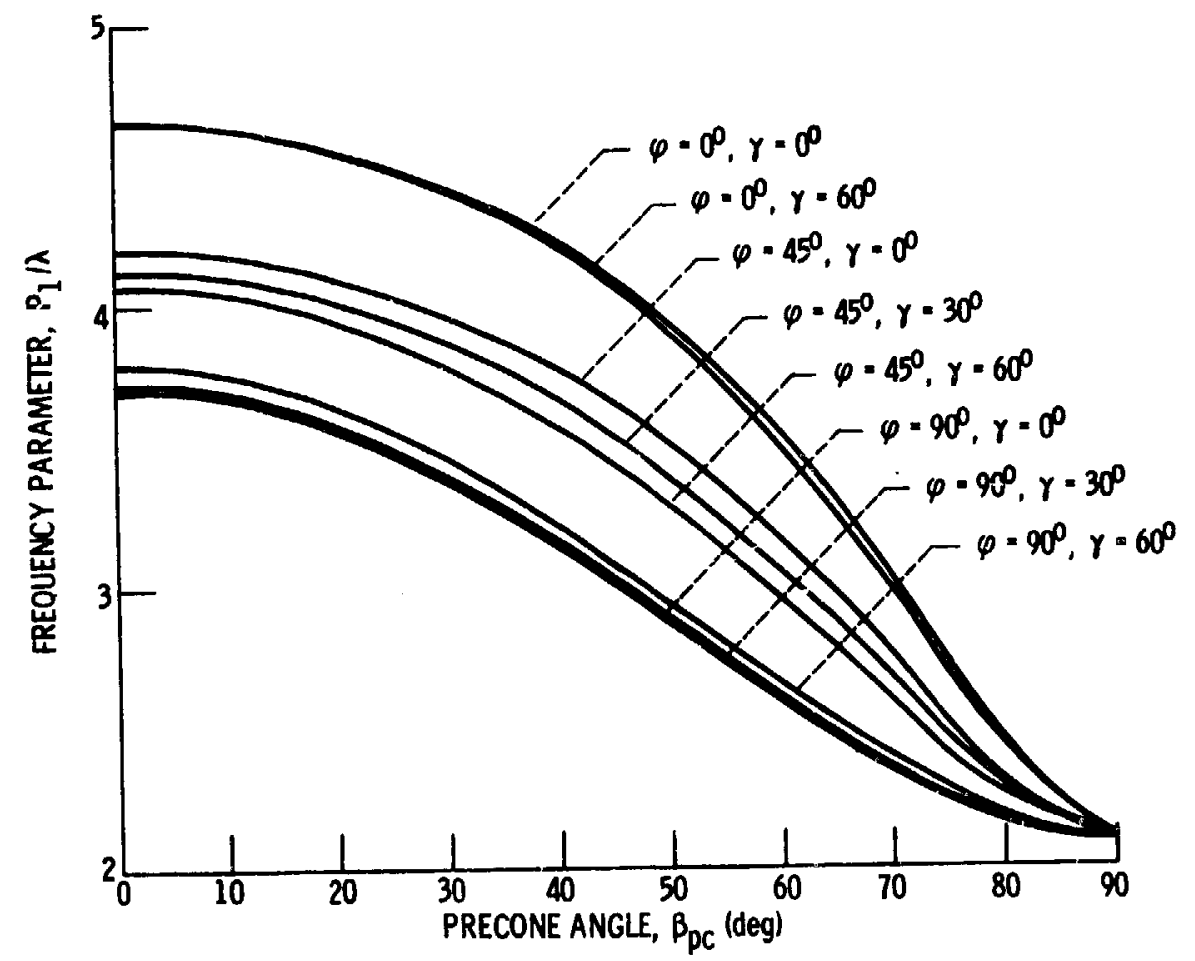

Figure 3. - Effect oi pretwist, precone and setting angle variations on the fundamental mode frequency parametar of rotating, thin, blade: Perturbation solution: $d / b=0.05, \Omega / \omega_{1}=0.8, L / b=10, L=5.0 \mathrm{in}$. 


\begin{tabular}{|c|c|c|c|}
\hline $\begin{array}{l}\text { 1. Report No. } \\
\text { NASA TM-87102 }\end{array}$ & in No. & 3. Recipient's Cata & \\
\hline 4. Title and Subritie & & 5. Report Date & \\
\hline $\begin{array}{l}\text { Nonlinear Flap-Lag-Extensional Vibrations } \\
\text { Rotating, Pretwisted, Preconed Beams Inclu } \\
\text { Cortolis Effects }\end{array}$ & of & 6. Performing Orga & on Code \\
\hline $\begin{array}{l}\text { 7. Author(s) } \\
\text { K.B. Subrahmanyam and K.R.V. Kaza }\end{array}$ & & $\begin{array}{l}\text { 8. Performing Orga } \\
\text { E-2598 }\end{array}$ & on Feport No. \\
\hline & & 10. Work Unit No. & \\
\hline 9. Performing Organization Name and Addres 3 & & & \\
\hline $\begin{array}{l}\text { National Aeronautics and Space Administrat } \\
\text { Lewis Research Center } \\
\text { Cleveland ahto } 44735\end{array}$ & ion & 11. Contract or Gran & \\
\hline 12. Sponsoring Agency Name and Address & & $\begin{array}{l}\text { 13. Type of Report al } \\
\text { Technical }\end{array}$ & $\begin{array}{l}\text { rlod Covered } \\
\text { Horandum }\end{array}$ \\
\hline $\begin{array}{l}\text { National Aeronautics and Space Administrat } \\
\text { Washington, D.C. } 20546\end{array}$ & ion & 14. Sponsoring Agen & \\
\hline $\begin{array}{l}\text { 15. Supplementary Notes } \\
\text { K.B. Subrahmanyam, on leave from MBKR Institute of } \\
\text { Department, Vidyanagar } 524413 \text {, India and Research As } \\
43606 \text {; K.R.V. Kaza, MASA Lewis Research Center. Pre } \\
\text { Conference sponsored by the Ohio State University, C }\end{array}$ & $\begin{array}{l}\text { cience } \\
\text { sociat } \\
\text { pared } \\
\text { olumbu }\end{array}$ & $\begin{array}{l}\text { logy, Mechanica } \\
\text { ty of Toledo, } \\
\text { h widwestern } \\
\text { ptember 9-11, }\end{array}$ & $\begin{array}{l}\text { gineering } \\
\text { o, Ohio } \\
\text { ics }\end{array}$ \\
\hline $\begin{array}{l}\text { 16. Abstract } \\
\text { The effects of pretwist, precone, setting angle, cor } \\
\text { linearities on the natural frequencies, steady state } \\
\text { torsionally rigid, cantilevered bear.s are studied in } \\
\text { equations of flap-lag-extensional motion are derived } \\
\text { ponent of sweep) and retaining geometric nonlinearit } \\
\text { with nonrotating normal modes, is used for the solut } \\
\text { linear perturbation equations. Parametric results } \\
\text { of pretwist, precone, Coriolis forces and second deg } \\
\text { deflections, natural frequencies and mode shapes of } \\
\text { results lnoicate that the second degree geometric no } \\
\text { produce frequency changes of engineering significanc } \\
\text { mode, and about } \pm \text { percent on the second mode). Fur } \\
\text { second degree nonlinearities in the ansiysis is achi } \\
\text { those generated by mSC MASTRA. The results further } \\
\text { effects must be included in analyzing thick blades wi } \\
\text { thin blades, typical of advanced turboprop blade con } \\
\text { cant on the first flatwise and the first edgewise mo } \\
\text { those modes where the effect is significant, the lin } \\
\text { another, the nonlinear effects generally being stron }\end{array}$ & $\begin{array}{l}\text { iolis } \\
\text { defie } \\
\text { this } \\
\text { inclu } \\
\text { ies up } \\
\text { ion of } \\
\text { ndicat } \\
\text { ree ge } \\
\text { rotati } \\
\text { nlinea } \\
\text { e (of } \\
\text { ther c } \\
\text { eved b } \\
\text { indic } \\
\text { hile t } \\
\text { figura } \\
\text { des, b } \\
\text { ear an } \\
\text { ger. }\end{array}$ & $\begin{array}{l}\text { second degree } 9 \\
\text { mode shapes of } \\
\text { on. The govern } \\
\text { fects of large } \\
\text { degree. The Ga } \\
\text { y state nonline } \\
\text { ividual and col } \\
\text { linearities on } \\
\text { re presented an } \\
\text { ich vanish for } \\
\text { fo percent on } \\
\text { of the validit } \\
\text { ns of bean theo } \\
\text { e linear and no } \\
\text { s Can be neglec } \\
\text { coriolis effec } \\
\text { gnificant on hi } \\
\text { Coriolis effec } \\
\end{array}$ & $\begin{array}{l}\text { tric non- } \\
\text { ting, } \\
\text { coupled } \\
\text { one (a corr- } \\
\text { in method, } \\
\text { quations and } \\
\text { ive effects } \\
\text { steady siate } \\
\text { scussed. The } \\
\text { precone, can } \\
\text { fundamental } \\
\text { including } \\
\text { esults to } \\
\text { ear coriolis } \\
\text { in analyzing } \\
\text { re signifi- } \\
\text { modes. For } \\
\text { ppose one }\end{array}$ \\
\hline 17. Koy Words (Suggested by Author(s!) & 18. Olsi & & \\
\hline $\begin{array}{l}\text { Nonlinear differential equations; Coupled } \\
\text { vibration; Rotation; Pretwist; Precone; } \\
\text { Corlolis effects; Second degree geometric } \\
\text { nonlinearities }\end{array}$ & & $\begin{array}{l}\text { d-unilmite } \\
\text { ry } 39\end{array}$ & \\
\hline $\begin{array}{l}\text { 19. Socurlty Clasalf. (of thlo report) } \\
\text { Unc lass if fed }\end{array}$ & $\begin{array}{l}\text { page) } \\
\text { pifiec }\end{array}$ & 21. No. of papes & 22. Price" \\
\hline
\end{tabular}

"For sale by the National Technical Information Service, C--.-afielc, Virginia 22161 